\title{
London's Hadrianic War?
}

\author{
By DOMINIC PERRING
}

\begin{abstract}
Recent work has advanced our understanding of human crania found in London's upper Walbrook valley, where skull deposition appears to have peaked during the occupation of the Cripplegate fort, itself probably built soon after London's Hadrianic fire. Although this fire is usually considered to have been accidental, parallels can be drawn with London's Boudican destruction. This article explores the possibility that these three strands of Hadrianic evidence - fire, fort and skulls — find common explanation in events associated with a British war of this period. This might support the identification of some Walbrook skulls as trophy heads, disposed as noxii in wet places in the urban pomerium.
\end{abstract}

Keywords: London; Hadrian; Walbrook skulls; head-hunting; Hadrianic fire; Cripplegate fort; revolt

\section{THE WALBROOK SKULLS}

$\mathrm{T}$ he Walbrook skulls have long excited antiquarian curiosity. They were a possible inspiration for Geoffrey of Monmouth's twelfth-century description of a massacre of Roman soldiers beside a brook, which he associates with late third-century events. ${ }^{1}$ Mid-nineteenth-century sewer-digging encountered 'immense numbers of human skulls' in Blomfield Street, London Wall and Copthall Avenue, while many more were found by workmen on nearby building sites between 1860 and $1934 .^{2}$ Some of these early finds reached museum collections where they appear darkly stained, reflecting their waterlogged burial environment. Some were identifiably from Roman contexts, pre-dating the town wall, while several were described as found on the gravel stream-bed encouraging the idea that they had been detached from bodies by water action. ${ }^{3}$ Wheeler noted that the presence of crania alone might indicate that they had been deposited along the stream banks by storm-water, the rounded shape of the skull accounting for its greater mobility compared with other remains, and therefore suggested that a large collection of human remains awaited discovery upriver. ${ }^{4}$

Geoffrey of Monmouth, Historia regum Britanniae 5.4.

Lane Fox 1867; Norman and Reader 1906.

Reader 1903.

Wheeler 1928, 15. 
Wheeler also tentatively suggested that some skulls were from victims of Boudica's revolt in A.D. 60/61, an idea which remained popular until Marsh and West's comprehensive reassessment of the evidence. ${ }^{5}$ This established that most skulls in museum collections, 48 of which were examined, were from young males. They are unlikely, then, to have been the old and infirm supposedly abandoned to rebel slaughter. ${ }^{6}$ Noting the absence of unusual pathologies, Marsh and West drew attention to the ritual connotations of watery burial and suggested that the Walbrook skulls were deposited in religious practice. ${ }^{7}$ The argument that the skulls illustrated Celtic veneration of the human head has consequently gained wide acceptance. ${ }^{8}$ Cotton's useful update on this research found parallels with the evidence of headless war or sacrificial victims from late Iron Age Gaul, suggesting an association between head cults and decapitation rites. ${ }^{9}$

Marsh and West's study also stimulated renewed interest in skull deposition within the Thames, where Knüsel and Carr drew on taphonomic studies to show that the clustering of crania could be caused by the fluvial sorting of bodies that entered the Thames by other means. ${ }^{10}$ This does not fully account for the distribution of the evidence, while subsequent research highlights an association between late prehistoric river skulls and contemporary weaponry found within the river, suggesting a common origin in votive activity. ${ }^{11}$ These Thames skulls show a relatively wide date-range, although radiocarbon dating of three Walbrook skulls confirmed their late Iron Age or Roman date.

A recent reassessment of skulls in museum collections found a more even gender distribution than earlier studies, identifying 10 male and 12 female skulls from a sample of $33 .{ }^{12}$ This may reflect, in part, on changes in analytical methodologies. Metric data suggested that a significant proportion derived from a Romano-British/Iron Age population. The presence of mandibles suggested that at least 10 per cent entered the water as either complete heads or bodies. This study also noted that the condition of the material was consistent with rapid submersion in organic deposits in a slow-moving river or fen bog. None of the skulls within this sample showed signs of fatal pre-mortem injuries, although several witnessed healed traumas.

Skulls were comparatively rare discoveries in later twentieth-century archaeological excavations, reflecting the limited sampling of deeper-lying features and a neglect of 'natural' river deposits. Four recent studies have, however, added important information. Excavations at Moor House (1998-2004) on the marshy margins of the Roman settlement, revealed second-century ditch systems containing human skull parts and long bones associated with horse bones. A deliberate selection of human remains appears to have taken place, as they also displayed evidence of post-mortem knife cuts and dog gnawing. Although these finds were disturbed by both water action and ditch recutting, Butler suggests that the evidence may derive from the ritual manipulation of skulls and long bones, perhaps associated with excarnation rites inherited from the pre-Roman Iron Age. ${ }^{13}$

Excavations around Eldon Street (1987-2007) examined a small roadside cemetery where 135 burials, mostly inhumations dated after $c$. A.D. 120 , were catalogued. ${ }^{14}$ Most were set along a major channel that fed into the Walbrook. Some had inescapably been eroded by watercourse migration and flooding, as human remains were consequently also present within the stream

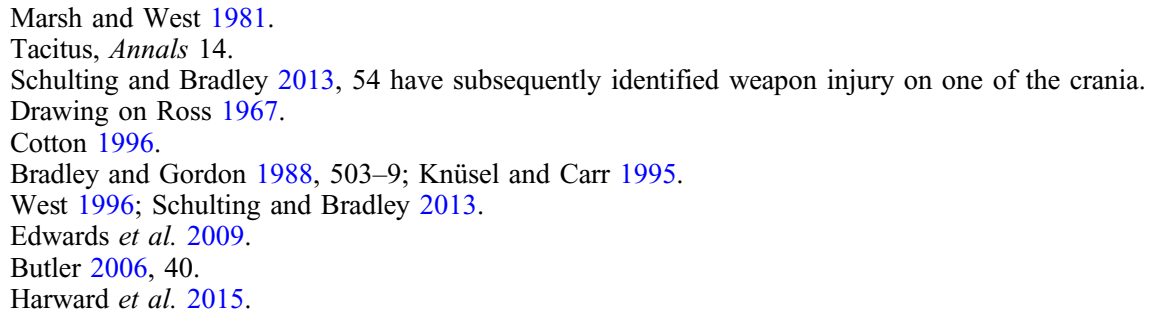


channel. These disturbed remains included both isolated skulls and groups of skulls. These discoveries encouraged a wider reassessment of Walbrook heads, introducing taphonomic evidence to suggest that crania had washed out from burial grounds upstream. ${ }^{15}$ Forensic literature illustrates how crania roll further along streams than other human remains, allowing them to be carried in disproportionate numbers to river bends where they are deposited. ${ }^{16}$ Heads are also more easily identified, resulting in their over-reporting in comparison with other skeletal remains washed out of the cemeteries.

A different picture emerges from a study of 39 skulls found on the west bank of the Walbrook at 52-63 London Wall. ${ }^{17}$ These had been left to decompose in waterlogged pits, while dog gnawing and puncture marks show that remains with soft-tissue had been exposed to scavenging. The lack of weathering indicates, however, that this was unlikely to have taken place over an extended period. Associated pottery suggested that the skulls were deposited from c. A.D. 40 to 200, but the stratigraphic evidence suggests a much narrower date range and the groups were probably deposited in their entirety sometime between $c$. A.D. 120 and $c$. A.D. $160 .{ }^{18}$ Almost all the skulls came from young males, 28-35 years old, and most carried injuries inflicted around the time of death. Many had healed wounds, one including a shattered cheek typical of a violent blow, and there was a clear case of decapitation with a sword. The violence unleashed was grossly excessive. This assemblage differs from other human remains from the Walbrook, hence Redfern and Bonney suggest that these were trophy heads, perhaps from contests and executions in the nearby amphitheatre or brought to London from wars elsewhere. The skulls showed no signs of having been modified for display, or otherwise curated post-mortem, although it remains possible that decomposing material had been displayed before disposal. Skull integrity does not, however, seem to have been an important consideration since facial bones were frequently damaged.

The latest discoveries of Walbrook skulls were made during the construction of Crossrail, near where Liverpool Street (and coincidentally an earlier Roman road) crossed the Walbrook. These finds are the subject of ongoing work by the Museum of London. ${ }^{19}$ Skulls were recovered from two main areas. In 2013 tunnelling operations came across 35 skulls within gravels dumped against the east bank of the Walbrook in late second-century engineering works. Radiocarbon dating provisionally indicates that at least one skull was earlier than $c$. A.D. 80 while another appears no earlier than late second century. ${ }^{20}$ Preliminary analysis suggests that all but a few were male. Some were polished by water action and others pockmarked from being washed along with river gravel. Nearby excavations revealed a timber jetty or hardstanding formed from two reused doors dated by dendrochronology to A.D. 110-34. Subsequently, in 2015, 20 more skulls were found in a Hadrianic roadside ditch on the eastern approach to the Walbrook crossing, most placed at intervals along the southern side of the road.

\section{THE CONTEXT OF SKULL DEPOSITION IN LONDON}

In sum, while most Walbrook skulls came from the stream-bed, many others are found in wet places in the environs of the river (Appendix: Table 1). These include roadside drains and pits

15 Powers 2015, 127-34.

16 Haglund 1993.

17 Lees et al. 1989, 116; Redfern and Bonney 2014.

18 Redfern and Bonney 2014, 216.

19 Keily 2017, 58-60. I am grateful to Jay Carver, Don Walker and Al Telfer for providing additional information.

20 The different dates suggest that the gravel had been quarried from a part of the river-bed where disparate remains had come to rest. The earlier skull might indicate a point of origin some distance down-stream, where first-century finds are more common. 
containing standing water. The studied skulls are disproportionately those of young males. Altogether over 300 are listed in published accounts, further to 'immense numbers' found in sewer-digging. Most derive from poorly dated river deposits, but those found within pits and ditches were buried $c$. A.D. 120-65, a time when extensive engineering introduced a planned grid of streets to an area previously on the marshy margins of the Roman city. Details of this building programme will be considered further below, but the undated river finds were concentrated close to roads and bridges that did not exist prior to $c$. A.D. 120. They also came from contexts likely to pre-date the construction of the city wall in c. A.D. 200. Skull deposition appears, therefore, to concentrate in the mid-second century, although individual examples can be dated between the first and third centuries. Drawing on our understanding of the urban topography of this district it is difficult to identify a source for large numbers of skulls here prior to $c$. A.D. 120 or after c. A.D. 200. Indeed, on the basis of the dated assemblages, it is feasible that most were deposited within a few years of each other sometime between A.D. 120 and A.D. 165 (and with some, at least, belonging to the period before A.D. 140). Although the skulls could have been deposited over a short period, it remains possible that they had been gathered and displayed over a longer time frame, potentially drawing on material from earlier cemeteries, before being dispatched into wet places, where post-depositional reworking may have further delayed final burial.

The skulls were found in an area likely to have lain outside town at the time of their deposition. The upper Walbrook valley lay to the north-west of a substantial bank and ditch that probably marked the Flavian town boundary. ${ }^{21}$ The town wall, built $c$. A.D. 200, subsequently enclosed much of this area. Although ditches preceding the wall suggest that the extended urban circuit was marked out before it was monumentalised in stone, there is no certain date for when this took place. ${ }^{22}$ The distribution of human remains in the upper Walbrook can, however, be more readily understood if the Flavian boundary continued to define London's legal limits until the late second century.

At least 29 isolated human crania have been recovered from elsewhere in Roman London (Appendix: Table 2 and FIG. 1). While some may have derived from disturbed graves this cannot have been the case in most instances. As with the upper Walbrook skulls, they were usually found in wet locations such as wells, pits, ditches and ponds formed from abandoned quarries, although some were placed in ditches associated with cemeteries. The contexts range in date, but half were buried in the first century with a peak in the Flavian period. The earlier skulls were found singly, concentrated along the main west road into town and adjacent to the Thames. The presence of skulls in deposits associated with Thames waterfront reclamation might be the residual evidence of a wider practice of votive river deposition. Several skulls were found in features that may have marked the town limits at the time of their deposition, including three within the second-century fills of the ditch thought to form the Flavian town boundary (FIG. 1.42). It may be significant that all skull groups, as opposed to single finds, appear to date to A.D. 120-65. Skull deposition in the upper Walbrook may consequently derive from earlier practice, which similarly involved sinking human crania into wet places at liminal roadside locations on the borders of the urban settlement, but on a much increased scale.

The exceptional nature of the second-century concentration of skulls in the upper Walbrook deserves emphasis. The record of over 300 crania represents a significant part of the total of human remains recovered from Roman London. By comparison some 2,180 Roman burials have been recorded from London's main cemeteries, with at least 320 of these consisting of cremations. ${ }^{23}$ In all cases archaeological recovery provides only a small sample of the original

Howe 2002; Perring 2015, 29.

Wilson 2006a, 15-17.

Hall 1996, 83; updated by Pearce 2015, table 1. 


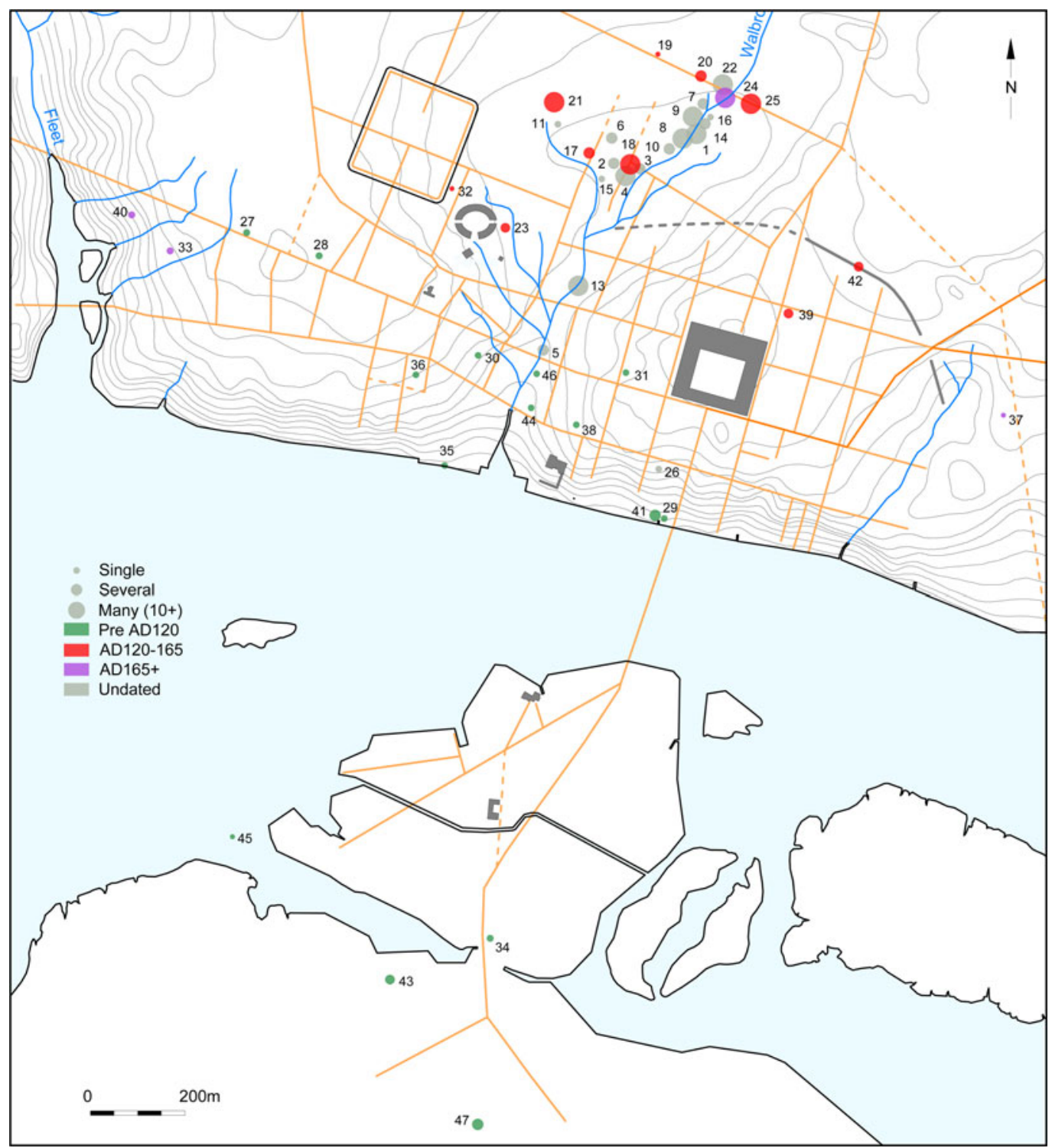

FIG. 1. Plan showing the distribution of human crania found in Roman London. (Drawing: J. Russel)

population. Significantly less than 5 per cent of relevant deposits in the upper Walbrook valley has been investigated. An exact figure is difficult to establish, but records of sewer excavations and archaeological investigations encompass about 5 per cent of the projected line of the Walbrook. In those parts of the valley where detailed surveys have been undertaken these similarly illustrate limited sampling. Maloney's detailed descriptions of investigations at 15-35 Copthall Avenue and 43/44 London Wall show that under 4 per cent of the fills of the roadside ditches were archaeologically sampled and the river channels in this area were barely explored at all. ${ }^{24}$ 
While it is possible that attention has been disproportionately drawn to the locations where skulls were deposited, it is equally possible that even larger concentrations have escaped attention in deeply buried 'natural' deposits. If a sample of significantly under 5 per cent has produced over 300 skulls - for the most part recovered without systematic effort - then it follows that significantly more than 6,000 skulls might originally have been present. This figure is not to be taken seriously, given the uneven distributions of both skulls and archaeological investigations, but it provides a crude sense of scale.

What then might account for such exceptional numbers? We have three main hypotheses to consider: that fluvial erosion carried heads downstream from burials exposed in earlier cemeteries; that skulls were gathered from other sources before being ritually deposited in wet places in votive practice; or that violently obtained trophy heads were disposed of in unusual numbers. These are not mutually exclusive possibilities and different assemblages could have been formed in different ways.

It is evidently the case, however, that skulls found in stagnant wet places and roadside ditches could not have been carried directly to these locations by fluvial action. It is also impossible to identify an upstream source of burials to account for large numbers of skulls within the river. Extensive investigation between Moorgate and Bishopsgate shows that the area north of the Roman settlement remained under-utilised pasture and marsh. ${ }^{25}$ Numerous excavations have confirmed the absence of cemeteries throughout almost all of this area, while disturbed human remains were not present in 'natural' or residual contexts. The only exception is the unusual Eldon Street burial ground, where 104 adult inhumations have been found along a suburban road. Here the burials occupied a narrow strip little more than $20 \mathrm{~m}$ wide. ${ }^{26}$ A mixed deposit of human bone found in the later town ditch at 85-6 London Wall may derive from the erosion of burials from an eastern extension to this burial ground, but could incorporate disturbed burials and excarnated remains of slightly later date. ${ }^{27}$ Using figures drawn from the most densely packed part of the cemetery and generously assuming that burials extended the full 300 -m-length of the road within the Walbrook catchment, the relevant part of the cemetery could have housed no more than 3,000 burials. Since grave density is demonstrably lower in many areas this exaggerates a burial population that might equally have been limited to a few hundred souls. Although up to 40 per cent of the graves were missing skulls because of later disturbance, this was usually a consequence of subsequent excavations rather than river erosion. Altogether only 15 of the burials were identified as having been disturbed by flowing water and where the skull was one of the missing body parts. The number of missing skulls is more than balanced by the number of detached crania, 19 in all, recovered from the same area.

This evidence leads to the conclusion that while some burials were washed into tributaries of the Walbrook, the numbers involved are too few to account for the bulk of the evidence. The larger and longer-used cemeteries along Bishopsgate were beyond the reach of the channels of the Walbrook and it is not possible to reconstruct any patterns of flood erosion that would have carried significant numbers of skulls from here into the Finsbury Circus area. Disturbed cemeteries are unlikely to have been the direct source of most finds. It is more likely that most skulls entered the water through direct human agency, as was demonstrably the case for the non-fluvial finds. It is consequently reasonable to identify a deliberate pattern of disposing of human remains, disproportionately the heads of young men, in the river and associated wet places. The deposition of skulls and bodies in wet places is widely attested in northern Europe in both the Iron Age and Roman period. Lakes, springs and bogs are liminal places on the

Maloney and de Moulins 1990, fig. 44a.

e.g. Cipin 2015, 10 .

Harward et al. 2015, fig. 16. Eight further burials were found in Crossrail excavations: Keily 2017, 58.

Schofield and Maloney 1998, 242-3; Hall 2014, 167. 
threshold between the living and other worlds. ${ }^{28}$ The deposition of skulls in boundary ditches is also likely to have been influenced by a widespread association of heads with gateways and thresholds that constituted sacred borders separating the worlds of the living and the dead. ${ }^{29}$ The places in London where skulls were found are also areas where horse remains were unusually frequent and, while this was probably the product of a common approach to the disposal of human and horse remains within the urban pomerium, it might additionally reflect on the fact that the horse could serve as a psychopomp.

The idea of a particularly 'Celtic' cult of the head is, however, difficult to sustain. Skulls and heads were differently deployed in ritual practice according to local cultural circumstance. ${ }^{30}$ Whatever the detailed nature of the belief systems that resulted in skull presentation and burial, these must be set within the wider systems of understanding that applied to the treatment of the dead.

\section{THE UNBURIED DEAD}

Ritual practices involving excarnation took place in both late Iron Age and Roman Britain, the study of which has concluded that some instances of late Iron Age corpse mutilation and exposure are likely to have been directed at enemy captives. ${ }^{31}$ It is distinctly possible that Roman London incorporated ideas that pre-dated the conquest in its treatment of the dead, but in most respects the new city adopted burial practices that were similar to those found in other Roman towns. ${ }^{32}$ It consequently makes sense to look to the wider evidence of Roman practice to understand how and why skeletal remains entered the Walbrook.

Roman burial involved acts of purification and expiation, situated in graveyards removed beyond the city's sacred limits by both custom and rule. ${ }^{33}$ The corpse demanded respect since it was believed that departed souls would suffer if the body was not buried. ${ }^{34}$ Funerary rites were therefore important sacred duties that involved propitiating the spirits of the dead, whose trespass in the land of the living threatened misfortune. Proper burial required the body to be covered, even if poetic licence accepted three handfuls of dust as sufficient token, and it was an offence to damage bodies during burial or after interment. ${ }^{35}$ These rights extended to enemies killed on the battleground and executed criminals, where the reunion of decapitated heads with the buried corpse was an important concession to the bereaved. ${ }^{36}$ Recent research suggests that burials with repositioned skulls sometimes found in Romano-British cemeteries, including those in London, include victims of decapitation. ${ }^{37}$

Denial of burial was, instead, an exceptional punishment reserved for those who challenged public and social order and particularly those considered guilty of treason and betrayal. ${ }^{38}$ In such cases corpse abuse could include decapitation, followed by a denial of burial rites and exposure to scavenging by wild dogs and birds, combining to achieve the public obliteration of victims in a damnatio memoriae. ${ }^{39}$ Some Roman descriptions of decapitation treated it as a

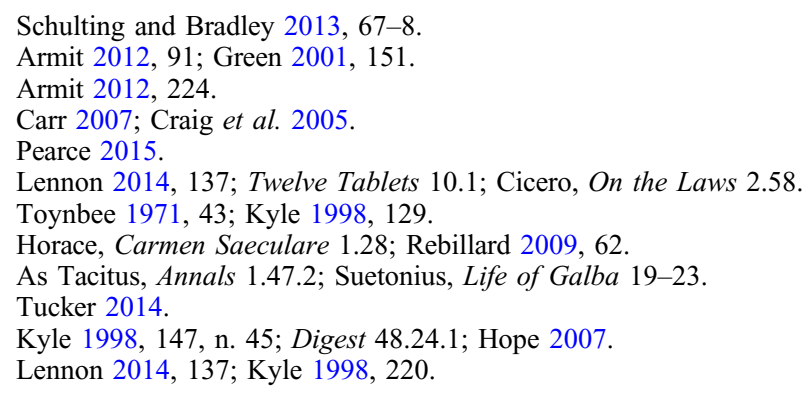


form of mutilation after death, in which heads were exploited for display and abuse, as much as a form of execution. ${ }^{40}$ The distancing of the head from the body meant that funerary rituals could not be properly enacted nor the remains properly interred.

These unburied dead risked contaminating sacred areas, including those defined by the city's boundary. ${ }^{41}$ Their remains therefore required some form of ritual expurgation to prevent spirits from troubling the living. Rome consequently developed mechanisms to remove unburied human remains and purify the city. It used the Tiber to purge itself and, as a consequence, river disposal came to be closely associated with corpse abuse and the denial of burial. The river formed a religious boundary to the sacred area of Rome and was a place where the impure could be removed to other realms. ${ }^{42}$ Several histories make a point of describing how the bodies of those who betrayed Rome were dragged to the Tiber. ${ }^{43}$ In an extreme example the bodies of executed Samnite prisoners were thrown into the Tiber in their thousands after the Battle of the Colline Gate. ${ }^{44}$ Other slaughter gave Cicero, himself destined to have his decapitated head displayed in the Roman forum, rhetorical licence to describe the Tiber and sewers of Rome as filled with bodies. ${ }^{45}$ Throwing bodies into the Tiber or Cloaca Maxima removed the unworthy from both place and memory, in an exceptional punishment that was both logistically practical and symbolically reassuring, where 'the lustral magic of the living water took away the pollution and brought purification against hostile spirits'. ${ }^{46}$

The evidence from the Walbrook, although open to other interpretations, is consistent with the picture obtained from Rome. Like the Cloaca Maxima and Tiber, the Walbrook and Thames formed sacred boundaries to the settlement they circumscribed. While the Tiber might appear a distant analogy for the archaeology of Roman London, a direct connection is found in the career of Statius Priscus, who served as curator of the bed of the Tiber and sewers of Rome after earlier military service in Britain, before becoming governor of the province $c$. A.D. 161.47 While Rome must have witnessed extremes of politically motivated corpse abuse, similar practices are documented in other cities. Eusebius, for instance, describes the A.D. 177 execution of Christian martyrs from Lyon and Vienne, some of whom were beheaded in the amphitheatre; the bodies of these victims were mutilated by beasts, exposed for six days under guard to prevent their burial, then burnt and swept into the Rhône. ${ }^{48}$

The upper Walbrook valley formed part of the city pomerium, an area favoured for the execution and burial of criminals. It also lay north-west of the city, a direction naturally associated with mortality beyond the setting sun. ${ }^{49}$ This area also formed part of the hinterland of London's amphitheatre, which itself occupied liminal space. Redfern and Bonney identify the arena as a possible source of some of the crania they studied. ${ }^{50}$ One idea they explore is that some heads came from people killed in gladiatorial combat, since this would account for the injuries sustained, while the bodies of amphitheatre combatants were sometimes excluded from formal burial grounds and funerary practices. ${ }^{51}$ It seems unlikely, however, that vast numbers of gladiators would have been treated in this fashion. Capital punishment by decapitation offers a more credible context for the widespread separation of heads from corpses

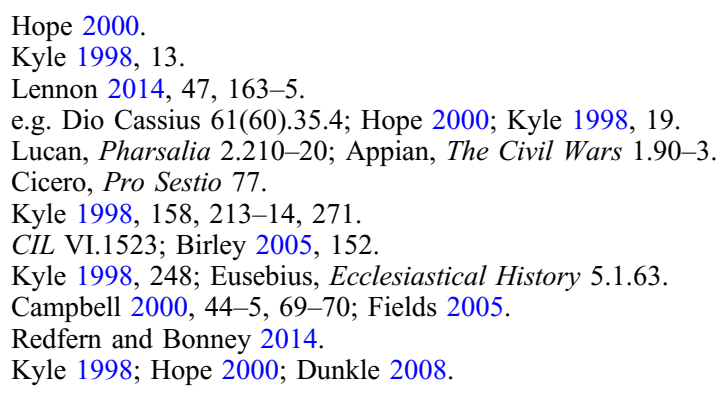


at the amphitheatre. ${ }^{52}$ Citizens of status might be offered a quick and discrete beheading on the bounds of the settlement, but most of the condemned were publicly executed in the amphitheatre. ${ }^{53}$ The unwanted corpses of these noxii risked being excluded from burial and consequently disposed of in the river. ${ }^{54}$

London is bound to have witnessed frequent executions, as the city held a pivotal role in Rome's administration of Britain, remaining under the direct command of the provincial governor until at least the early Flavian period. ${ }^{55}$ The governor's judicial duties included imposing the death sentence and ordering public execution. ${ }^{56}$ The second-century tombstone of Celsus, speculator of Legion II Augusta found near Blackfriars, witnesses the presence in London of those officers responsible for judicial killing. ${ }^{57}$ While speculatores might have been responsible for decapitations that resulted in skulls being ritually removed to the Walbrook, it is difficult to believe that massive numbers of victims normally warranted such treatment. The number of skulls from the Walbrook stands comparison with the 6,160 executions undertaken at Tyburn tree in the reign of Elizabeth I, a period of equivalent duration to the Hadrianic/ Antonine peak of skull disposal. ${ }^{58}$ Elizabethan London, however, grew to house 200,000 people, a figure many times greater than the 25-30,000 estimated to have lived in second-century London. ${ }^{59}$ It is, in any case, unlikely that more than a small fraction of execution victims would have had their heads removed. Decapitation was but one of a variety of forms of capital punishment and, as has already been noted, the bodies of those executed were normally released to relatives for burial.

\section{TROPHY HEADS}

The evidence marshalled by Redfern and Bonney suggests that some skulls were trophy heads of the sort most readily obtained in warfare. Although the violence witnessed in the London Wall assemblage marks these out as victims of exceptional punishment, they are not the only Walbrook skulls to present evidence of weapon injury. ${ }^{60}$ While most heads do not show equivalent evidence of trauma this does not preclude them from being the product of head-hunting, as decapitation is usually only identifiable in trauma to upper vertebrae, which bones are usually missing. ${ }^{61}$

There is credible evidence for head-hunting in Britain prior to the conquest. Skulls, nearly all adult males, are found in shafts and wells at various pre-Roman sites. ${ }^{62}$ The evidence concentrates at hillfort sites, sometimes in boundary ditches and near gateways, where crania display weapon injuries. ${ }^{63}$ Wait concludes that such skulls were probably the product of martial head-hunting and that their disposal was not so much a feature of mortuary ritual as the votive or apotropaic treatment of the potent heads of enemy dead. ${ }^{64}$ This is consistent with our wider understanding of head-hunting in Iron Age Europe and the display and post-mortem manipulation of

Hope 2000; Ash 1997; Bauman 1996, 151; Varner 2005, 69.

Kyle 1998, 53.

Hinard 1987, 119; Kyle 1998, 217-20.

Tomlin 2016, 56; Perring 2015, 25.

Furhmann 2012, 171-4.

RIB I.19; Combe et al. 2015, 46.

Marks 1908, 77.

Harding 1990; Swain and Williams 2008, 33.

Schulting and Bradley 2013, 54; Marsh and West 1981, 97.

Clarke 1979, 415; Tucker 2014, 214.

Wait 1985, 51-82.

63 e.g. Green 2001, 104; Walker 1984; Hencken 1938.

64 Wait $1985,117,20$. 
decapitated heads in pre-Roman Gaul. ${ }^{65}$ While these pre-Roman finds might give credence to Greek and Roman sources that treated the display of trophy heads as a disturbing Celtic practice, Roman histories make it clear that head-hunting also featured in Roman military practice. ${ }^{66}$

In Roman accounts decapitation and the display of severed heads was particularly associated with the punishment of sacrilegious treason, emphasised in descriptions of civil war, rebellion and desertion, and proscriptions under Sulla and the Second Triumvirate. ${ }^{67}$ Other histories describe the decapitation of defeated emperors and usurpers whose heads were paraded as proof that they no longer threatened public order. ${ }^{68}$ Much of this blood-letting was undertaken by Roman soldiers, with victims' heads being brought to Rome for display on the Forum rostra before finding their way into Rome's rivers and sewers. ${ }^{69}$

By the end of the first century head-hunting activities were sometimes associated with auxiliary troops raised in the north-west provinces, echoing earlier Gallic warrior behaviour now integrated with Roman military identities. ${ }^{70}$ This is illustrated by scenes from Trajan's Column (scenes 71, 24 and 113) showing soldiers, identified as Gallic auxiliaries by their shields, holding the severed heads of Dacian warriors slain in battle; elsewhere on the Column legionaries are shown building a road next to two heads mounted on poles outside a town or fort gate (scene 56). ${ }^{71}$ Other Trajanic monuments show that head-hunting was a publicly acknowledged practice within the Roman army of this period. Rome's recruitment of auxiliary cavalry from Gallic and Germanic provinces may have contributed to an evolution of battlefield practice where, 'for a Celt now serving in the Roman army, head taking was still an organized, coherent form of violence in which the severed head retained its specific ritual meaning'. ${ }^{72}$ Such activities may have become acceptable in an army that, with Hadrian's encouragement, was increasingly willing to learn from customs previously considered barbarian. ${ }^{73}$

Tombstones show that head-hunting practices were openly professed by members of the auxiliary cavalry deployed in Roman Britain. The late first-century memorial to Aurelius Lucius from Chester showed this cavalryman's groom holding up a severed head, while a tombstone of $c$. A.D. 75-120 at Lancaster shows Insus, a citizen of the Treviri and trooper with the Ala Augusta, on his horse grasping the head of his decapitated enemy. ${ }^{74}$ Isolated skulls found on Romano-British sites are often identified as possible trophies. ${ }^{75}$ A direct association with the activities of the army is suggested by such discoveries at Romano-British forts. Skull fragments in Flavian pits at the fort at Newstead are thought to represent discarded military trophies, while the skull of a young male dated c. A.D. 200 found in the fort ditch at Vindolanda had sword wounds to the head. ${ }^{76}$ The London evidence can also be set within the context of discoveries from neighbouring Roman towns. At Colchester six skulls, mostly young

Armit 2012, 197, 223.

66 ibid., 25-6; Diodorus Siculus 5.29.4-5; Strabo, Geography 4.4.5; Livy, History of Rome 10.26.11; Voisins 1984; Fields 2005; Goldsworthy 1998.

67 Lucan, Pharsalia 2.103; Livy, History of Rome 24.30.6; Valerius Maximus 9.2.1; Caesar, Spanish War 32; Appian, The Civil Wars 1.71 .

68 Varner 2005, 70; Ash 1997.

69 Furhmann 2012, 96; Appian, The Civil Wars 4.2.5-4.20; Plutarch, Life of Antony 20; Life of Cicero 48-9; Lennon 2014, 157; Kyle 1998, 132-3, 220-4.

70 Fields 2005; Goldsworthy 1998.

71 Coarelli et al. 2000.

72 Fields 2005.

73 Arrian, Tactica 33.1-2; Birley 1997, 288; Haynes 2013, 76.

74 RIB I.522; RIB III.3185; Bull 2007. A drawing on a writing-tablet from Vindolanda also appears to show a line of soldiers with a severed head at their feet: Birley 2002, 34.

75 Isserlin 1997, 95; other examples summarised in Pearce 2013, 100-1.

76 Curle 1911, 113-14; Hanson 2012, 70; Ross and Feachem 1976; Loe 2003. 
males and some showing trauma associated with weapon injury and decapitation, were found in the town ditch. They are interpreted as victims of executions that had been placed on public display. ${ }^{77}$ The cranium of a youth was also found at the base of a late second-century shaft in the temple precinct at Folly Lane, Verulamium. This showed evidence of blunt-force injuries suggesting that death was caused by a blow to the skull, while cut marks indicate deliberate defleshing. ${ }^{78}$ There are suggestions that this decapitated head had been displayed before being buried. The exposure of heads and body parts, thought to derive from victims of Roman judicial and military violence, witness excarnation rituals that share characteristics with late Iron Age practice.

There is compelling evidence that martial head-hunting and corpse abuse took place in early Roman Britain, practices which may have contributed to skulls being deposited in ditches and pits at liminal sites associated with the Roman administration.

\section{THE HADRIANIC FIRE}

If the Walbrook skulls included victims of martial head-hunting it is likely that such practices continued for the first two centuries of Roman rule. The large number of mid-second-century finds suggests the massive increase of a practice that normally involved no more than a handful of trophies. This hints at unusual slaughter, at one or more events in the period c. A.D. 125-65. The alternative possibility that long-curated skulls were brought together in an unusual intensification of votive disposal cannot be dismissed, but the skulls show no signs of having been curated with care and at least some were disposed of with soft tissue surviving.

Redfern and Bonney have noted that the date ascribed to the Walbrook skulls fails to correspond to other evidence for war or unrest that might have affected London. ${ }^{79}$ This begs the question of how we might recognise such conflict. London features in no written histories between those concerning the Boudican revolt and events of A.D. 296, hence we can draw few conclusions from a silence that reflects on the absence of interested historians rather than the absence of history. The archaeological evidence offers more promise. The example of London's destruction by rebels in A.D. 60/61 reveals how war might leave archaeological traces: the razing of the city was witnessed by a bright red destruction horizon, while the years following the revolt were marked by building activities consistent with military reoccupation. ${ }^{80}$ Since a remarkably similar pattern emerges from the archaeological record of the period A.D. 125-30, this opens the possibility that this was also a product of war. Numerous excavations have identified a Hadrianic destruction horizon, ${ }^{81}$ although the possibility that this was the product of political disturbance has been dismissed for the want of corroborating evidence. ${ }^{82}$

Near-contiguous sightings of fire debris indicate that a single conflagration destroyed London north of the Thames, an area of $c .64 .5$ ha. The burnt remains of timber-and-clay buildings left a thick horizon of bright red burnt clay, although the event is harder to trace in open areas and where masonry architecture was employed (as is also the case with stone buildings caught up in the Great Fire of 1666) ${ }^{83}$ Irrespective of whether the fire started at London Bridge, as has been speculated, ${ }^{84}$ destruction can be traced to the limits of the pre-Hadrianic settlement in almost every direction

Crummy 1984, 94-7; Benfield and Garrod 1992, 37.

Mays and Steele 1996.

Redfern and Bonney 2014, 222.

Perring 2015, 26-8; Dunwoodie et al. 2015.

Dunning 1945; Roskams and Watson 1981.

Dunning 1945, 60.

Porter 1996, 49; Schofield 1994, 25.

Perring 1991, 72; Dunwoodie et al. 2015, 118. 


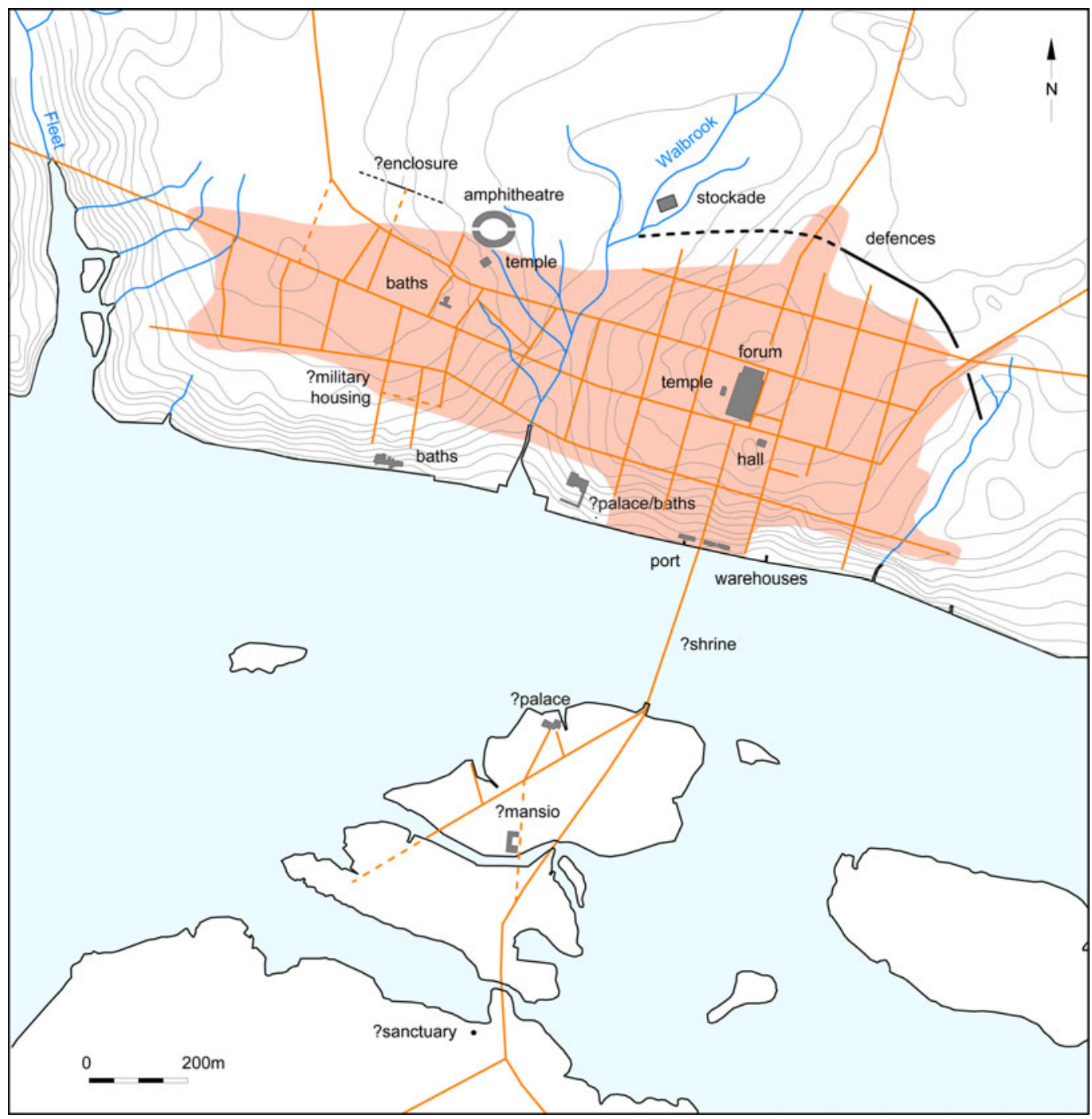

FIG. 2. Plan showing the probable extent of the Hadrianic fire in relation to the urban topography of the early second century (the forum is shown in its Flavian rather than Hadrianic layout). (Drawing: J. Russel)

(FIG. 2). The fire is well attested either side of the approaches to London Bridge, where quays and warehouses were damaged to the river's edge. ${ }^{85}$ The Walbrook failed to act as a fire-break and destruction is evident on both sides of its lower reaches, as at the junction of Cannon Street and Dowgate Hill. ${ }^{86}$ The fire may not have reached the waterside on lower terraces further to the west, perhaps because there was little here to burn. The Flavian bath-house at Huggin Hill probably fell into disuse before the fire, as deposits associated with disuse of the caldarium 
contained Trajanic pottery, while earth-walled buildings within the disused shell of the complex may not have been built until later. ${ }^{87}$ Otherwise destruction extended to the western limits of the town. Early second-century fire-destruction debris west of St Pauls Cathedral marks the limit of Hadrianic housing along the road towards Fleet Street. ${ }^{88}$ Fire debris has also been found along Roman Newgate Street, certainly extending west to the Merrill Lynch Financial Centre site and possibly to 3-9 Newgate Street where a 'localised fire of c AD 100-120' was identified. ${ }^{89}$ Here too destruction appears to have extended to the outermost fringes of the settlement.

Fire debris can be traced across most sites immediately south of the amphitheatre, but the conflagration left no trace within the arena itself. ${ }^{90}$ The Flavian amphitheatre was dismantled c. A.D. 125 , clearing the site for the construction of its masonry successor, and it has been suggested that timbers from its structure were salvaged for reuse leaving a short hiatus between the two phases of building. ${ }^{91}$ The decision to rebuild the amphitheatre in stone has been associated with Hadrian's visit of A.D. 122, in which case the area could have been an open building site at the time of the fire. It is alternatively possible that the rebuilding was necessitated by partial fire damage. In any case the amphitheatre marked the northern extent of the fire in this part of London. Land around the amphitheatre was left open for access and crowd control and the complex consequently formed the boundary of both pre-Hadrianic settlement and fire destruction..$^{92}$

Further east, the fire horizon was evident on both sides of the Walbrook crossing at One Poultry, east of which the urban core was extensively destroyed. ${ }^{93}$ Buildings flanking the forum were burnt to the ground, as evidenced at Lombard Court, Birchin Lane, Lime Street and Fenchurch Street. ${ }^{94}$ It is less certain that the forum itself was destroyed, although second-century destruction debris is attested and will be discussed further below. North of the forum, the fire has been traced through 7-11 Bishopsgate to Threadneedle Street and probably as far as the settlement then extended. ${ }^{95}$ This may have included suburban roadside development beyond the urban core, suggested by fire-destruction debris of this approximate date at 76-86 Bishopsgate. ${ }^{96}$ Burnt material at Winchester House in Old Broad Street is, however, a poorly dated outlier and best excluded. ${ }^{97}$

Evidence of the fire has been traced east from the forum, certainly as far as Plantation Place and Mark Lane, but not as far as the Tower of London where there is no certain occupation before the late A.D. 120s. ${ }^{98}$ Destruction debris also extended north-east along Fenchurch Street as far as Lloyd's Registry and St Katherine Coleman and may have affected sites up to 3-4 Jewry Street. ${ }^{99}$ There are, however, a few buildings on the eastern margins of the settlement, chiefly those set back from the street frontages, which show no direct evidence of fire damage. ${ }^{100}$

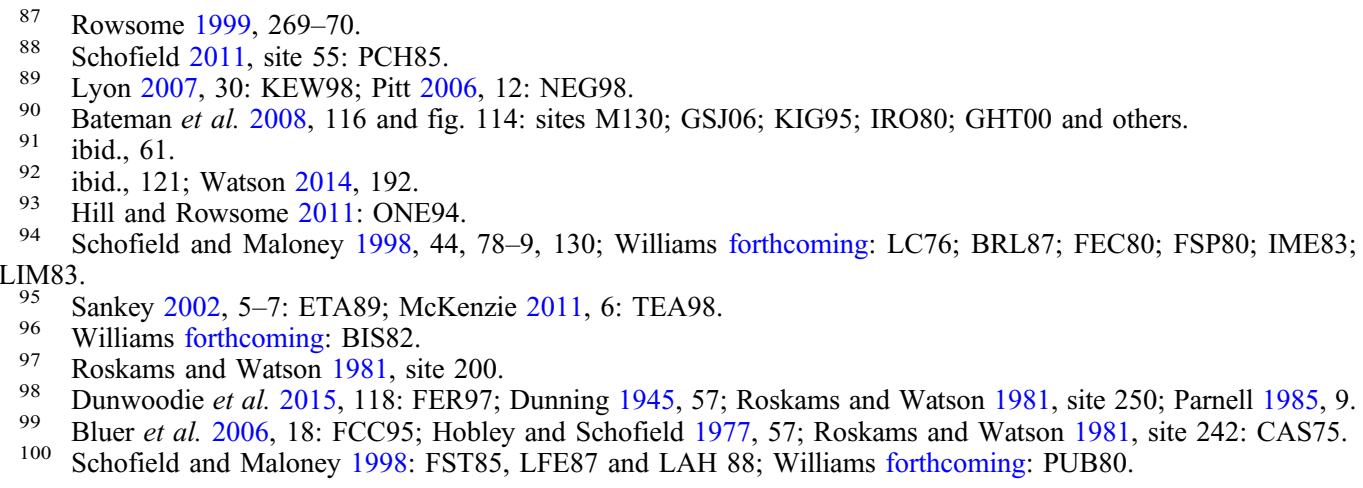


Fire debris is generally absent from the upper Walbrook valley and Cripplegate fort, perhaps because these areas were not developed until after the fire. The other part of London lacking a clearly defined Hadrianic fire horizon is Southwark. Recent excavations at 11-15 Borough High Street and 2 London Bridge Street have revealed a horizon of burnt material and in-situ collapse that pre-dated the early or mid-second-century construction of a bath-house, but since other parts of Southwark appear to have been untouched this is more likely to have been an isolated local fire. ${ }^{101}$

The evidence combines to indicate that the destruction of London north of the Thames was unusually comprehensive. In an accidental fire one would expect to find areas of buildings saved downwind of the fire's starting point and in peripheral areas where reduced building densities left natural fire-breaks, as was evident in the Great Fire of 1666. This was not the case and the nature of the destruction is therefore more consistent with arson. This might also account for choices made over what to save from the disaster. While most valuables appear to have been removed, the sheets of a bronze diploma granting Roman citizenship were fused together in fire damage to a town-house at Watling Court. ${ }^{102}$ This was an odd thing to have abandoned, since easily portable and precious to the recipient and his heirs, but more easily overlooked by looters. Disturbed human remains were also found in fire debris at Watling Court, although these might have been intrusive. ${ }^{103}$ While the evidence is far from conclusive, the example of the Boudican fire provides a parallel for the Hadrianic fire, as both could have been the consequence of war destruction (as hinted at by unusual aspects to post-fire reconstruction that are considered further below).

\section{THE DATE OF THE FIRE}

The fire is commonly dated $c$. A.D. 125 on the basis of a warehouse assemblage of over 600 samian vessels found at Regis House, on the Thames waterfront. ${ }^{104}$ Elsewhere coins of Trajan (A.D. 98117) have been recovered from floor surfaces beneath the fire horizon, as at One Poultry and Lime Street. ${ }^{105}$ The absence of Hadrianic issues is unsurprising since early second-century supply is meagre. ${ }^{106}$ Pottery found in fire debris at One Poultry is consistent with the waterfront evidence and included numerous potter's stamps from les Martres-de-Veyre samian (SAMMV) including Indercillus and Viducus ii. ${ }^{107}$ These date closely to $c$. A.D. 105-25. The debris also contained some black burnished ware 2 (BB2) and Cologne colour-coated ware (KOLN), dated c. A.D. $100-40$, as well as a single Pulborough samian vessel made from a Lezoux mould dated $c$. A.D. 125-50. ${ }^{108}$ This would be late for Pulborough production and questions the dating of the mould, but reinforces the impression that the fire is unlikely to have happened before $c$. A.D. 125 .

Reports on buildings excavated at 10 Gresham Street in 1997-2002 confusingly describe two successive periods ending in Hadrianic conflagration, both dated c. A.D. 130 by assemblages, including diagnostic forms in Verulamium region whiteware. ${ }^{109}$ The excavators suggest that there may have been several devastating fires, but the presence of successive fire horizons is not demonstrated in the published data and the structural sequences seem inconsistent with the

101 Chris Constable, pers. comm.

102 Roxan 1983; Haynes 2013, 339-42: WAT78.

103 Perring and Roskams 1991, 41.

104 Marsh 1981; Symonds 1998, 340.

105 Hill and Rowsome 2011, 132, 353.

106 Julian Bowsher, pers. comm.

107 Hill and Rowsome 2011, 355.

108 ibid., 162.

109 Casson et al. 2014, 37, 61-2, 86-92: GSM97. 
proposed dating. While we cannot be certain that all observations of Hadrianic fire debris derive from a single event, the presence of a near-contiguous destruction horizon that crossed many major roads and boundaries strongly points towards this having been the case.

Dendrochronological dating of structures pre-dating the fire does not improve on the chronology suggested by the pottery. A well destroyed at Gresham Street employed timbers dated A.D. 108/9, while a warehouse destroyed on the Pudding Lane waterfront was built with timbers felled A.D. 94-129. ${ }^{110}$ A new waterfront was built at Regis House in or immediately after A.D. 102 and is thought to have remained in use for some decades before being burnt. ${ }^{111}$ Archaeomagnetic samples from fire debris at this site provide dates of A.D. 110-30 and 130-80. While these two samples are only reconciled by the date of A.D. 130, the tolerances of archaeomagnetic dating are insufficiently precise for this to be treated as absolute.

These observations have, however, encouraged archaeologists to revise the accepted dating of the fire to A.D. 125/130. A slightly later date may make it easier to accommodate the evidence of fire destruction obtained from excavations of the forum at Leadenhall Court. ${ }^{112}$ A vast new basilica was built here early in the second century. It is likely that this grand project was occasioned by Hadrian's visit to Britain in A.D. 122 and it conforms to wider evidence of Hadrian's civic patronage. ${ }^{13}$ If this were the case, work on London's new basilica could have started soon after Hadrian's trip was conceived, perhaps as early as A.D. 119. ${ }^{114}$ Deposits associated with the construction of the north range of the basilica included ceramics (principally BB2) dated c. A.D. $120 .{ }^{115}$ This building underwent a major phase of modification, involving the replacement of the nave wall with brick piers, before destruction in a fire of Hadrianic date. Might it be possible that the arrival of the imperial party resulted in hurried design changes? A road built along the north side of the basilica at the time of its construction had been resurfaced twice before this fire. Roads in early London are known to have been resurfaced at four- to five-year intervals, although the imperial visit and alteration of the basilica nave are both events that might have encouraged swifter attention to road repair. ${ }^{116}$ While it is possible that these alterations were completed within five years, a longer time frame is more likely. ${ }^{117}$ If we accept a start date of A.D. 119/122 for the construction of the basilica and assume a minimum of three years between each road repair, this would place the earliest possible date for the fire here at A.D. 125.

Although a date of $c$. A.D. 130 might seem a better fit for some of the evidence, a slightly earlier date is indicated by the dendrochronological dating of post-fire waterfront reconstruction to A.D. 128. Several observations indicate that timber quays were rebuilt in the Hadrianic period, replacing earlier second-century revetments such as those built at Regis House in or soon after A.D. 102. ${ }^{118}$ The most telling observations were made in excavations at Suffolk House in Cannon Street, east of the so-called Governor's Palace. Here an early second-century quay reused a timber felled A.D. 90-121 and incorporated pottery assemblages indicating a construction date $c$. A.D. 100-20.119 It seems likely that these quays were built in association with the construction of the forum and other early Hadrianic buildings c. A.D. 120. This waterfront was unusually short-lived and soon replaced. Dumps associated with the replacement waterfront contained burnt and sooted pottery dated A.D. 120-60, likely to be material damaged

110 Blair et al. 2006, 18-20: GHT00; Hillam 1986, 14.

111 Brigham and Watson 1996: KWS94.

112 Milne 1992, 70: LCT84.

113 SHA, Hadrian 12; Boatwright 2000.

114 Birley 1997, 101-4.

115 Milne 1992, 68.

116 Perring and Roskams 1991, 51-6.

117 Milne 1992, 70.

118 Brigham 1998, 29: KWS94.

119 Brigham and Woodger 2001, 20: SUF94; waterfront 3. 
in the Hadrianic fire, while in-situ Hadrianic fire debris was found nearby. ${ }^{120}$ These observations combine to suggest that the Hadrianic fire had damaged the second-century waterfront and was the reason why the quays needed replacement. The post-fire quay was probably built in A.D. 128, since this was the date of timbers used to build a box-drain that formed part of the new arrangements. In early London it was normal for timbers to be felled on demand and the Hadrianic fire would in any case have reduced supplies of reusable timber. ${ }^{121}$ Since the building of the new drain was occasioned by the waterfront advancement associated with post-fire rebuilding, the date of A.D. 128 suggests a terminus ante quem for the Hadrianic fire.

There is one further piece of dating evidence to consider. A substantial jetty built over the Thames foreshore, which was found in the inmost ward of the Tower of London in 1977, used timbers felled in the winter of A.D. 126-7. ${ }^{122}$ This was the earliest structure found in the area, which probably lay outside the then town limits some considerable distance east of London's earlier Roman port. This was a curious date and location for substantial waterfront activity. In the light of other evidence summarised here, it is tempting to suggest that the jetty was built to exploit a location convenient for shipping coming upriver during a period when London's port remained damaged beyond use. This permits a tentative reconstruction of events in which temporary works were planned between autumn A.D. 126 and spring A.D. 127, preceding the rehabilitation of the urban port in A.D. 128.

Before turning to the evidence of post-fire military reoccupation, it is worth drawing attention to the bronze head of the emperor Hadrian recovered from the Thames just below London Bridge. Recent study shows that this casting was probably commissioned from a London workshop and may have been made to coincide with the imperial visit of A.D. $122 .{ }^{123}$ The statue from which the head had been roughly hacked was intended to be viewed from the front and likely to have stood prominently within a niche in the contemporary new forum.

Most scholars have assumed that the head was removed from the statue in late antiquity, probably by iconoclasts. There is, however, no evidence for this. Since forum and basilica were extensively damaged by fire in the Hadrianic period, it is difficult to see how the statue would have escaped destruction at this time unless it had been moved. This suggests an alternative context for the events that resulted in its decapitation and the disposal of Hadrian's head in the waters of the Thames. There are other instances of heads being removed from imperial statues and thrown into rivers in ritual acts of desecration analogous to the abuse vested in trophy heads. ${ }^{124}$ Here the decapitation of the imperial image mirrored corpse abuse and could have symbolised the rejection of Hadrian's imperial authority, while also drawing on wider practice in the ritual disposal of body-parts from bronze statues in water to expel spirits from the image. This event could have happened soon after the statue was first erected rather than centuries later, hence unintentionally saving the head from fire damage.

\section{THE CRIPPLEGATE FORT}

London's Hadrianic military occupation is evidenced by the Cripplegate fort. This stone-walled playing-card fort, some $220 \mathrm{~m}$ by $215 \mathrm{~m}$ and occupying an area of $c .4 .7$ ha, was set on high ground north-west of the Roman city soon after c. A.D. 120 (FIG. 3). ${ }^{125}$ There are hints that the

24 Russell and Manley 2015, 166; Varner 2005, 67-88.

125 Howe and Lakin 2004; Shepherd 2012. 
site had been earmarked for public use in the early Flavian period. This is suggested by the awkward insertion into the urban topography of the road that led to the site of the fort's south gate, the excavation of a boundary ditch that anticipated the line of the fort's southern defences and the levelling of the area destined to become the fort interior. ${ }^{126}$ Excavations have, however, failed to find pre-Hadrianic barracks or defences and this Flavian enclosure may have been no more than a temporary annex or compound. The absence of Flavian barracks is not of itself conclusive, since such buildings were also absent from the fort built at Plantation House after the Boudican revolt where tents were possibly used instead. ${ }^{127}$

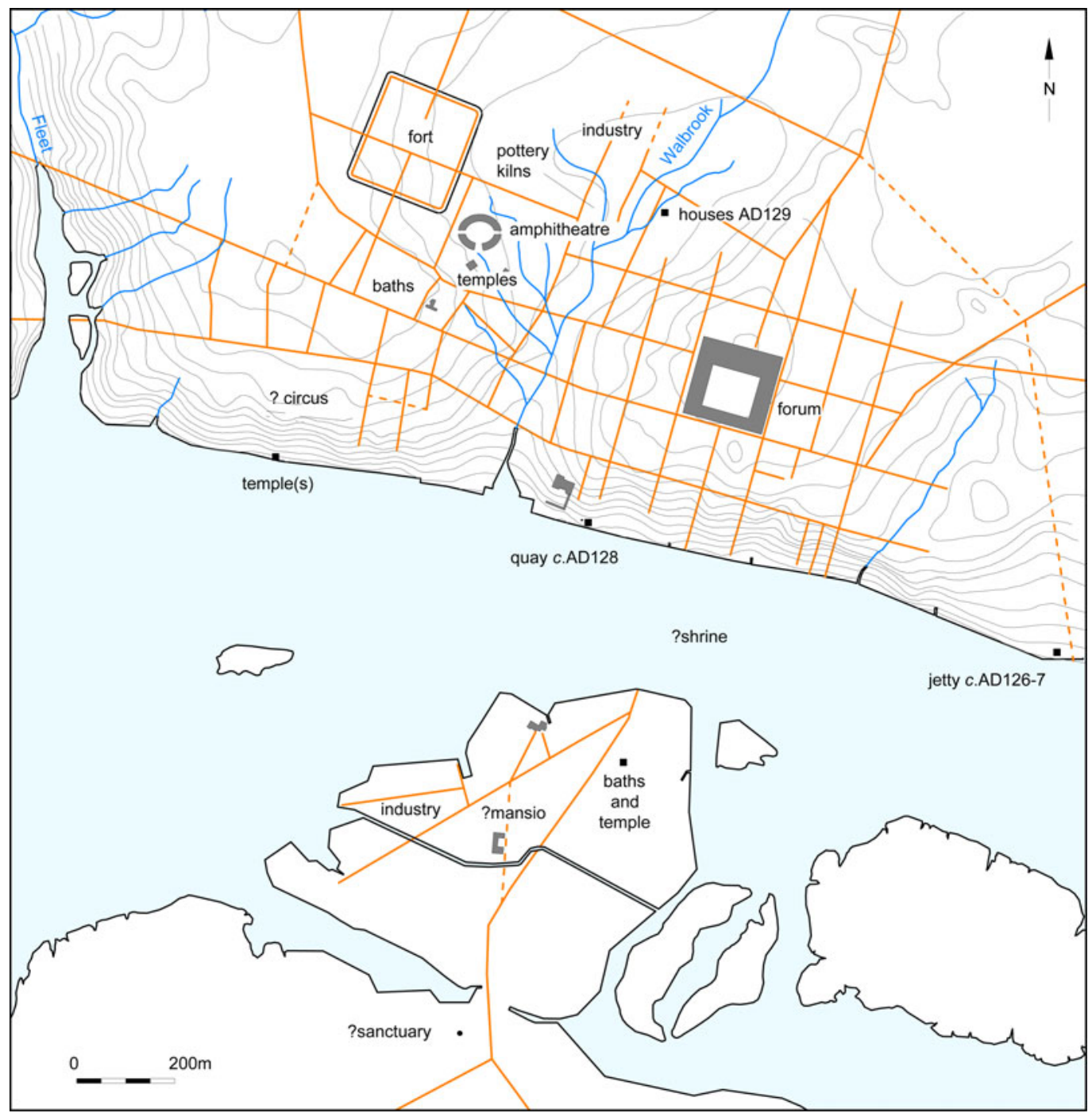

FIG. 3. Plan showing later Hadrianic London, after the construction of Cripplegate fort and vicus. (Drawing: J. Russel) 
Regardless of the Flavian arrangements, pottery within the fort bank includes samian that dates its construction to the A.D. 120s. ${ }^{128}$ Hadrianic fire debris is absent from within the fort, although layers of charcoal and burnt daub were observed beneath parts of its bank. ${ }^{129}$ It seems likely that the fort was built shortly after the Hadrianic fire, although an earlier date cannot be entirely excluded. The absence of pottery later than $c$. A.D. 165 from occupation deposits within the fort suggests that it had been evacuated at this time and certainly before the end of the second century, at which time the southern fort ditch was filled with silt and rubbish. ${ }^{130}$

The fort is an unusual feature since urban garrisons were a rarity in the Roman Empire. ${ }^{131}$ They were not, however, unknown. In addition to that at Rome, a cohort was based at Lyon by A.D. 21, apparently associated with the protection of the mint, while Vespasian stationed an urban cohort in Carthage. ${ }^{132}$ These garrisons protected Rome's interests in revenue collection and administered supply in cities that held unusual strategic importance. London's stone-built fort presented a similarly visible symbol of Roman authority and could indicate that London was also considered unusually important. ${ }^{133}$ It is commonly accepted that it housed soldiers serving the governor or otherwise seconded to London. The main component of such forces would have been the guard of auxiliary cavalry and infantry (singulares consularis), but included administrative staff working for the governor's office (officium), grooms (stratores) and functionaries associated with military supply (beneficiarii consularis). ${ }^{134}$ Numbers would have fluctuated, but up to 1,800 soldiers could have served in such capacities in London.

The fort was of a similar size to forts on the German frontier that housed cavalry alae, c. 1,000 strong; mixed units occupied less space. Objects within the fort suggest the presence of both legionaries and auxiliary troops, as well as cavalry and infantry, reinforcing the view that the fort contained a composite garrison. ${ }^{135}$ Parts of eight buildings, identified as barrack blocks, have been investigated in the southern part of the fort (praetentura). Assuming symmetry, this would allow for 18 or 22 buildings here. ${ }^{136}$ Most barracks probably housed infantry, with each capable of containing a century of $c$. 80 men. Two cavalry units (turmae), each of c. 32 men, would have occupied similarly sized blocks that probably included integrated stabling. ${ }^{137}$ This part of the fort could, therefore, have housed a mix of cavalry and infantry totalling some 1,350 men. The rear part of the fort is unexplored but would have included further barracks alongside working and storage facilities.

The fort was arguably larger than needed to house the full complement of soldiers routinely based in London. We must also assume the wholescale relocation of troops previously stationed elsewhere in London. The Vindolanda texts indicate that soldiers attending the provincial governor were based in London from at least c. A.D. $100 .{ }^{138}$ Houses at Watling Court were remarkably similar to contemporary centurion's quarters at Gloucester, but find no close parallel in civilian town-housing, and represent the sort of housing likely to have been occupied by the officer-class. ${ }^{139}$ At the time of its destruction in the Hadrianic fire one of these houses

Shepherd 2012, 154; Howe and Lakin 2004, 39, table 7.

Shepherd 2012, 50; Howe and Lakin 2004, 37.

Howe and Lakin 2004, 47; Shepherd 2012, 156.

31 Furhmann 2012, 45, 194; Pliny, Letters 10.77.

132 Furhmann 2012, 157

133 Shepherd 2012, 155.

134 Wacher 1974, 94; Speidel 1978, 26-8; Hassall 2012.

135 Howe and Lakin 2004, 57-8; Hassall 2012.

136 Howe and Lakin 2004, 55.

137 Davison 1989, 131.

138 Tab. Vindol. 154 and 310: Bowman and Thomas 1991, 72.

139 Perring and Roskams 1991, 30; Perring 2002, 62; Hurst 1999. 
contained a diploma granting Roman citizenship to a member of the auxiliary forces on completion of 25 years' service. ${ }^{140}$ This Flavian building possibly housed an auxiliary centurion on detachment to the singulares, who may still have been in service when awarded the diploma at a date between A.D. 98 and 108. There is no obvious reason why such officers needed relocating into the Cripplegate fort, although post-fire rebuilding might have encouraged a consolidation of scattered billeting arrangements onto a single site. ${ }^{141}$ If this had been the case, we would expect to find new centurions' houses within the Cripplegate fort that matched the scale and quality of the houses at Watling Court. There is no such evidence, while officers' quarters were notably absent from the barracks. ${ }^{142}$ This suggests that senior personnel serving with the governor were still housed elsewhere. The Cripplegate fort also fell into disuse sometime between A.D. 160 and 200, yet military attendances on the governor continued into the third century. ${ }^{143}$

In sum there was no evident need to build a fort to house the soldiers serving the governor and his administration, who could easily have lived elsewhere as they did in earlier and later periods. The fort was larger than needed and failed to include facilities for higher-ranked officers. The exercise also runs counter to normal imperial preference. The decision to station troops within a fort at London finds direct parallel, however, in arrangements after the Boudican revolt. ${ }^{144}$ The Cripplegate fort could have been built in response to post-fire political circumstance, involving the settlement of a new garrison of occupation, rather than in anomalous administrative display.

\section{THE VICUS}

East of the fort lay the upper Walbrook valley. This open land on the north-west margins of the Flavian city was crossed by small tributaries of the Walbrook and had attracted occasional suburban activities, represented by rubbish pits and irregular drainage ditches. ${ }^{145} \mathrm{~A}$ timber causeway at Drapers' Gardens may have been a temporary track built in the aftermath of the Boudican revolt, while an unusual Flavian palisade enclosure built in the angle of river channels here formed a stockade. ${ }^{146}$ These features may witness early military use and are consistent with the identification of this area as part of the city's pomerium.

A grid of streets, at least three aligned north-south and two east-west, was imposed on the area in the Hadrianic period (FIG. 3). This was a significant engineering exercise, involving the drainage and reclamation of marshy areas and the laying of gravelled road-surfaces on timber-and-turf causeways flanked by timber drains. ${ }^{147}$ Ceramic assemblages dating $c$. A.D. 120 were associated with the building of the new streets. Their orientation, which was slightly differently aligned to those of the urban core, and the date and location of their construction, suggest that they were planned in association with the contemporary building of the fort.

The absence of Hadrianic destruction debris from most upper Walbrook sites prevents us from conclusively establishing that these developments post-dated the fire, but this seems probable. At Angel Court, close to where the new street topography met the earlier city boundary, a layer containing burnt waste material, possibly from the Hadrianic fire, was redeposited in the construction of revetments associated with the re-engineering of the drainage of the

140 Roxan 1983; Haynes 2013, 339-42.

141 Howe and Lakin 2004, 50.

142 ibid., 59.

143 Hassall 2012, 166-8; Yule and Rankov 1998.

144 Dunwoodie et al. 2015, 64-72; Perring 2015, 23, 27

145 Maloney and de Moulins 1990, 85-8, 89-112, 114-15; Leary and Butler 2012, 78-83; Harward et al. 2015 , 15.

146 Butler and Ridgeway 2009; Perring 2015, 29: DGT06.

147 Maloney and de Moulins 1990, 26-39; Shepherd 1987; Bruce et al. 2009, 77. 
Walbrook. ${ }^{148}$ A terminus ante quem for the development of this new district is suggested by the use of several timbers felled in A.D. 129 in the construction of housing, a date which supports the suggestion that replanning of the upper Walbrook took place soon after the Hadrianic fire. ${ }^{149}$ The fort and adjacent area of new settlement were laid out alongside but avoided the earlier urban site, which was destined for reconstruction. There are parallels with the situation after the Great Fire of 1666, when London's displaced population was resettled in camps built on open land to the north of the ruined city. ${ }^{150}$

The new district resembled a fort vicus. The upper Walbrook was particularly suited to military activity, following Roman tradition of using the pomerium as a religious border to separate domestic and military spheres, with the army held beyond the sacred limits of the city. ${ }^{151}$ A vicus here might therefore have been considered distinct from the town and tolerant of activities otherwise excluded from the sacred bounds of the city (including industry, burial and military activity). From $c$. A.D. 110/20, kilns at 20-28 Moorgate made pottery of types closely associated with the military. ${ }^{152}$ Tanning and leather-working, both industries closely connected with army needs, were also important local industries. ${ }^{153}$ London's glass manufacture was relocated into the area, leading to much increased volumes of production. ${ }^{154}$ The overall scale of industrial production arguably exceeded the needs of the town and was more closely focused on the requirements of the military community. ${ }^{155}$ Manufacture continued into the Antonine period, but many kilns and furnaces ceased production $c$. A.D. 160/70 mirroring the chronology of activity within the fort. ${ }^{156}$

Rituals associated with the treatment of trophy heads may also have a bearing on finds of head-pots made in this district. There is a marked concentration of these vessels, dating from the late first century to $c$. A.D. 160, in the upper Walbrook. ${ }^{157}$ Elsewhere head-pots have been linked with the presence of auxiliary troops recruited from the Rhine delta and northern Belgium. ${ }^{158}$ In many contexts these vessels were probably ritual offerings and a cult use with Bacchic references has been suggested. ${ }^{159}$ Some pots resembled death masks, where the eyes were shown closed, accentuating links between the natural and supernatural realms. This would suit rites of transition in which the lifeless head represented the dead trapped in the world of the living. The coincident concentrations of human skulls and head-pots find parallel in what has been described as a "fluid relationship between real and carved heads, with both carrying similar meanings, and with the preference for one or the other shifting between different times and places' in the context of pre-Roman head-hunting. ${ }^{160}$ There may, therefore, be a connection between the rituals that resulted in the deposition of trophy heads and those that led to the burial of head-pots, both occurring within a vicus attached to the Cripplegate fort and tentatively associated with the presence of auxiliary forces.

\footnotetext{
148 Blurton 1977, 16-19, layer 16: ACW74.

149 Butler and Ridgeway 2009, 22: DGT06; Wardle et al. 2015, 9.

150 Reddaway 1940, 26.

151 Busch 2007, 317; Lennon 2014, 45.

152 Seeley and Drummond-Murray 2005, 142: MRG95.

153 Perring and Brigham 2000, 141.

154 Perez-Sala and Shepherd 2008; Wardle et al. 2015, 97.

155 Shepherd 2012, 156.

156 Wardle et al. 2015; Seeley and Drummond-Murray 2005.

157 Braithwaite 2007, 255, 348.

158 ibid., 323-403; Casson et al. 2014, 59-60.

159 Braithwaite 2007, 365, 395

160 Armit 2012, 162.
} 


\section{A MILITARY ROAD?}

The new district extended London's settled area northwards to the line later defined by the city wall. Beyond this a new road was built across open land. ${ }^{161}$ The point where this road bridged the Walbrook was a likely setting for the river-deposition of skulls, offering a practical and meaningful platform from which offerings could be made. The distribution of skulls within the stream-bed is consistent with the bridge having been one of the main entry-points for the human remains.

The road was built as part of the Hadrianic reorganisation of the upper Walbrook valley and is a puzzling feature, since no satisfactory explanation for its presence has been advanced. The evidence of its engineering is inconsistent with its interpretation as a minor track used to access areas of pasture and burial. A Trajanic coin (A.D. 96-117) was found in the road's construction and a Hadrianic coin from the fills of associated quarries, while ditches dug to divert earlier watercourses contained pottery assemblages with black burnished ware (BB2) dated soon after A.D. $120 .{ }^{162}$ Burials pre-dating but anticipating the line of the earliest road surface might indicate that it replaced an earlier unmetalled route defined by way-markers.

The road was some $5 \mathrm{~m}$ wide and its construction involved significant landscape engineering. It crossed an area of marshy pasture that saw frequent flooding and which included two substantial Walbrook channels in need of bridging. At Broadgate its construction involved a substantial brushwood foundation and several layers of gravel. ${ }^{163}$ The road was resurfaced only once, a repair dated after A.D. 154 by a coin of Antoninus Pius found within the road metal, but was not otherwise maintained. Parts of the road were disused by the end of the second century, following flood damage from poorly maintained water channels, and late second-century burials encroached on its line. ${ }^{164}$ It would appear, therefore, to have been built in response to some considerable need of temporary duration.

What then was its purpose? One possibility is that it was built to access the cemetery, but this seems unlikely. The small, low-status, burial ground at Eldon Street occupied a marshy and marginal area that was ill-suited for a cemetery. There was no compelling reason to invest in bridges, roads and causeways to reach this spot when large suburban cemeteries and areas into which these cemeteries could expand flanked major roads radiating from the city. It seems more likely that the burials were brought here by the road than the other way around.

A strategic purpose can, instead, be suggested. At its south-eastern end the road formed a junction with Ermine Street outside the later site of the city's north gate (FIG. 3). This junction might also have connected with an eastern route that bypassed the urban site to access the road to Colchester and waterfront facilities at the Tower of London. The north-western heading of the road aims directly towards a known crossing of the river Fleet at Battle Bridge (now King's Cross), where it was most easily crossed in the medieval period, so a Roman ford or bridge here is likely. ${ }^{165} \mathrm{~A}$ road that used this crossing would have carried traffic north-west from London, skirting higher ground to reach Watling Street short of where it crossed the Brent. This road would have provided a direct route to Verulamium avoiding London's town centre and the longer route via the Roman precursors to Oxford Street and Edgeware Road. The importance of Verulamium to the supply of London is illustrated by a contract to move goods from there to London prepared after the Boudican revolt, patterns of movement described in the Antonine Itinerary and official investment in pottery and tile production along Watling Street. ${ }^{166}$

161 Perring 2015, 33-4.

162 Harward et al. 2015, 24-5.

163 Harward et al. 2015, 79: XSM10.

164 Harward et al. 2015, 32-4.

165 Denyer $1935,13$.

166 Tomlin 2016, 156-9; Rivet 1970; Seeley and Drummond-Murray 2005, 142. 
It can be argued that the decision to build the road at this time reflected an increased level of concern to secure an important supply route, facilitating the movement of goods around London to and from Verulamium. This short-lived need coincided with the use of the Cripplegate fort. Road construction is frequently linked to army needs and it can be suggested that this route served such a purpose in the aftermath of the Hadrianic fire. ${ }^{167}$ It was then allowed to fall into disuse at about the same time as the fort was evacuated. A connection with military supply is also suggested by an unusual concentration of hipposandals along this route and around Moorgate. ${ }^{168}$ These contraptions were probably tied to hooves to improve traction on slippery roads and are associated with military supply routes. ${ }^{169}$ It is also worth noting that faunal remains from excavations around Eldon Street were dominated by horse bones, as was the case at other sites within and around the pomerium. ${ }^{170}$ Here the horses were mostly working animals, but drawing on stock that was distinctly taller than found on other excavations in London. This is consistent with the fact that the army had access to better livestock. ${ }^{171}$ These characteristics combine to suggest that this was an important military supply route, albeit short-lived, rather than a local access road.

The road's construction finds close parallel with the building of a timber corduroy that probably carried a track across the upper Walbrook in A.D. 62. ${ }^{172}$ This route was also a temporary feature that may have provided a strategic short-cut from Ermine Street to Watling Street and was one of the earliest features associated with the military reoccupation of London following the suppression of the Boudican revolt. ${ }^{173}$ A parallel example of military involvement in post-revolt reconstruction is evidenced by the deployment of a cohort of soldiers to build a road between Cyrene and its port in A.D. 118/19, within a few years of the razing of this city in the second Jewish revolt. ${ }^{174}$

This reassessment of the role of the Roman road at Eldon Street may help explain some unusual features to the burials found here. This was a strange place for a graveyard, the low status of which was suggested not only by its miserable location but by a low incidence of coffins and containers, an absence of animal bones associated with funerary meals and the placing of corpses in positions (prone and crouched) considered to mark lower-status burial. ${ }^{175}$ Deviant practices were indicated by decapitation burials that may have included execution victims and instances where iron rings had been used to bind the legs of the deceased. ${ }^{176}$ In one case a corpse appears to have been buried with its hands tied behind its back. Other unusual characteristics of this cemetery included a high male-to-female ratio and the under-representation of older adults. Unstratified human bones from the site also included defleshing cut-marks, perhaps witnessing excarnation and corpse abuse. ${ }^{177}$ These features might be explained if the cemetery originated as a place where the army buried those that had died in its custody, including prisoners and victims of capital punishment. Although the presence of this cemetery adds to the picture of an oppressive military presence in this part of Hadrianic London, it is important to note that these dead were treated differently to those whose skulls were found in wet places, not least because they were allowed burial. This graveyard also remained in occasional use into the early third century,

\footnotetext{
Roth 1999, 216-17.

168 Harward et al. 2015, 83-4.

169 Hyland 1990, 259; Dixon and Southern 1992, 229-31; Roth 1999, 203; Crummy 2011, 61.

170 Harward et al. 2015, 83-5.

171 Dixon and Southern 1992, 161.

172 Butler and Ridgeway 2009.

173 Perring 2015, 27.

174 Boatwright 2000, 177.

175 Harward et al. 2015, 92-100.

176 Tucker 2014, 230-1; Harward et al. 2015, 94-5, with three other decapitation burials found in the 2013 Crossrail excavations: Keily 2017, 58.

177 Harward et al. 2015, 126.
} 
suggesting that the deceased were buried in relatively small numbers over a century, in a tradition that outlasted the occupation of the Cripplegate fort.

The fort and its associated landscape suggest that London witnessed an increased military presence following the Hadrianic fire, coinciding with a significant increase in the ritual deposition of human crania in the upper Walbrook. These skulls appear to have been deposited within the pomerium, including a particular concentration at the point where a new road crossed the Walbrook, from which point river action may have carried skulls downstream. Other heads had been thrown into nearby wells, ditches and ponds within an area best characterised as a vicus attached to the fort.

\section{WAR IN HADRIANIC BRITAIN}

It is widely assumed that London reached a peak of prosperity in the Hadrianic period. ${ }^{178}$ Sources indicate, however, that Britain rebelled from Rome at this time, an event which might offer an historical context for the evidence summarised here. We lack detail on what happened, when or where, but Cornelius Fronto, writing to Marcus Aurelius in A.D. 162, described a slaughter of Roman soldiers by Britons that stood comparison with massive losses sustained in the Jewish wars. ${ }^{179}$ The late fourth-century life of Hadrian also refers to a failure to keep Britons under Roman control. ${ }^{180}$ This information was presented as part of a list of events which, if set out chronologically, would indicate that a British war occurred at the beginning of Hadrian's reign. This could also be the implication of Hadrianic coins showing Britannia and others that allude to military victory. ${ }^{181}$ As Hoffman has recently pointed out, however, it is uncertain whether the text recorded events in chronological order, while the Britannia coins could have been issued to commemorate Hadrian's visit of A.D. 122. ${ }^{182}$

Further discussion has focused on evidence of the military careers of Maenius Agrippa and Pontius Sabinus who served in an expeditio Britannica during Hadrian's reign. ${ }^{183}$ The reference suggests an active military campaign under imperial command, which might imply that it occurred during Hadrian's visit of A.D. 122. It is difficult, however, to see how a war involving the emperor would have escaped mention. Sabinus' career-path also suggests that he could not have participated in the expeditio before A.D. 124. ${ }^{184}$ Some scholars have therefore hypothesised a British war in the late A.D. 120 s or early 130 s. $^{185}$ Casey has instead drawn attention to successive coin issues from the mint at Alexandria that announced victories in A.D. $124 / 5$ and 125/6 and argued that these were won in the British war indicated by the sources. ${ }^{186}$ The evidence is inconclusive, but a victory obtained in the months prior to September A.D. 126 (the Alexandrian calendar year ran from September) is appropriately dated to have been won in a campaign that either followed or involved London's burning in A.D. 125 or 126.

It is usually assumed that the troubles would have been felt most fiercely in the North, where Rome faced a hostile frontier. An unsettled state of affairs is implied by the presence of exceptional numbers of auxiliary troops and the building of Hadrian's Wall, while a tombstone found at

178 Merrifield 1983, 112-14; Perring 1991, 73.

179 Fronto, Correspondence 2.

180 SHA, Hadrian 5.2.

181 RIC 577a and 577b; Birley 1997, 123.

182 Hoffman 2013, 140-3.

183 CIL XI.5632; X.5829; Jarrett 1976; Davies 1977; Frere 2000; Birley 2007; Breeze et al. 2012; Hoffman 2013.

184 Breeze et al. 2012, 27.

185 Frere 2000.

186 Casey 1987; followed by Hoffman 2013. 
Vindolanda commemorates a war casualty of this approximate period. ${ }^{187}$ The construction of Hadrian's Wall was disrupted at an early stage, allowing it to be suggested that building works were interrupted by an outbreak of fighting, while the subsequently reduced scale of works might indicate manpower shortages. ${ }^{188}$ Secondary forts were also added to defensive arrangements along the Cumbrian coast at a date after A.D. $125 .{ }^{189}$

There is also some evidence of destruction in southern Britain that might have a bearing on events in London. Early second-century fire-destruction horizons have been noted on roadside sites between London and Silchester, both at Brentford and perhaps Staines, where an adult skull was also found in a second-century well. ${ }^{190}$ These destruction horizons are not, however, closely dated and could equally derive from sporadic local fires. The evidence of the 'Classis Britannica' fort at Dover is more evidently relevant. This is the only other Hadrianic fort known from southern Britain and shares a similar chronology. The early fort at Dover could have been built any time between A.D. 115 and 125 but was abandoned incomplete. ${ }^{191}$ It was soon replaced by a slightly larger second fort, which numismatic evidence suggests was built in the period A.D. 125-40, before repair in the A.D. 150s. Pottery assemblages indicate that it fell into disuse in the early third century. The fort contained ten barrack blocks and may have housed components of the Classis Britannica whose brickyards provided tiles for its construction. As at Cripplegate the barracks lacked evident officers' quarters. The similarity in the chronologies proposed for the two forts might suggest a common inspiration, perhaps involving the protection of military supply at a time of insecurity. The interruption to the building programme at Dover, as with the dislocation episode in the building of Hadrian's Wall, could additionally evidence disruption caused by war. The fact that the Alexandrian coin issues appear to witness two victories in successive years might testify to an interrupted campaign.

If a British war had concluded $c$. A.D. 126, then victory may have been sufficiently comprehensive to allow the subsequent transfer of auxiliary units from Britain to other provinces. Units based in Britain in A.D. 122 had been withdrawn by A.D. 127, although these movements might have occurred before the outbreak of war. ${ }^{192}$ Other troop movements are implied by the arrival in Britain of Legion VI and the much disputed disappearance of Legion IX, both of which could date to this approximate period. The province still warranted the attentions of one of Rome's foremost generals, Julius Severus, in the early A.D. 130s. His transfer to Judea to take command against the Bar-Kokhba rebels in or soon after A.D. 132 must, however, mark the end of any serious concern over Britain's security. ${ }^{193}$

\section{HADRIANIC LONDON: A TENTATIVE NARRATIVE}

The evidence assembled here allows for a tentative rewriting of London's Hadrianic history. The emperor's visit in A.D. 122 provided a likely spur for a vigorous programme of public construction, consistent with what is known of Hadrian's role as a city benefactor. Tomlin has also suggested that this new architecture accompanied a formal grant of colonial status, based on his speculative reconstruction of an inscription found in the baths at Huggin Hill. ${ }^{194}$ The massive forum, where the emperor's bronze statue was likely placed, was the most visible manifestation of this

187 Holder 2003; Birley 1998

188 Hill 2006, 144; Breeze 2003, 13-16.

189 Frere $2000,26$.

190 Cowie et al. 2013, 18, 20; Parnum and Cotton 1983, 320; Sheldon and Schaaf 1978, 66; Jones 2010, 16, 20.

191 Philp 1981, 91-7; Breeze 1983.

192 Holder 2003.

193 Dio Cassius, Roman History 69.13.1-2; Eck 1999, 78-9; Birley 2005, 129-32.

194 Tomlin 2006 
Hadrianic munificence, but work on the replacement of the main town baths (perhaps transferred from Huggin Hill to Southwark) and amphitheatre (destined to be rebuilt in stone) may also have been put in hand at this time, along with new quays built to facilitate this programme. ${ }^{195}$ The palace at Winchester Palace in Southwark was also refurbished and enlarged, offering the kind of facilities that would have been needed to house the imperial entourage in A.D. 122.196 The emperor was probably accompanied on his visit by a new governor Platorius Nepos, whose later fall from imperial favour might reflect on events soon to occur. ${ }^{197}$

London was consequently in the midst of architectural change at the time of its Hadrianic destruction. Changes are also evident in pottery assemblages from the city. Locally produced Verulamium region whitewares (VRW) and imported black burnished vessels (BB2) mark the initiation of Hadrianic works in London and witness changing strategies in regional production and supply. ${ }^{198}$ Hadrian's building plans are likely to have been funded from local tax and rent, while increased expenditure would have demanded an increase in income. ${ }^{199}$ The emperor is known to have granted local taxes to support newly established cities and if he had granted London civic status then this might sensibly have been underwritten by a gift of local taxes and estates. ${ }^{200}$ Changing economic activity in the Thames estuary, an area that may have included imperial estates, is reflected in new patterns in the production and distribution of black burnished pottery (BB2). This appears to witness the early Hadrianic intensification of production, geared in part towards the supply of London. ${ }^{201}$ It is therefore credible that concerns similar to those that contributed to the earlier Icenian revolt were at issue in the Hadrianic period. ${ }^{202}$

Hadrian's visit to Britain was itself not trouble-free and is supposed to have involved tightening up army discipline and other reforms, which might also have had disruptive effects. ${ }^{203}$ If the Alexandrian Nike coin issues of A.D. 124/5 and 125/6 refer to events in Britain, then this was a war that followed Hadrian's visit to Britain rather than preceded it. The prompt for any such rebellion might date soon after Hadrian's tour of the western empire was abruptly broken off in A.D. 123, when an emergency appears to have summoned him to the East. ${ }^{204}$ It is credible that the example of the rebellions in Judea, and perhaps events elsewhere in Britain, left London vulnerable in the wake of Hadrian's departure.

The burning of London, if dated A.D. 125/6, could have been one of the final acts of a war that caused problems in both the north and south of Britain. That said, it is important to note that we have no other direct evidence for warfare in southern Britain at this time, although the interruption to the construction of the fort in Dover might have been provoked by military circumstances. It is possible that Hadrianic fire debris on sites in Staines and Brentford charts a route of destruction entering or departing London, but the evidence for this is far from compelling. The absence of equivalent destruction horizons at other towns in the South-East might indicate that the troubles, if such they were, remained local to London. Continuing with this line of speculation, it could be argued that Southwark avoided extensive destruction because the rebels failed to cross the Thames. The large numbers of heads brought to the Walbrook could indicate that victory was obtained nearby, since although trophy heads could be transported long distances,

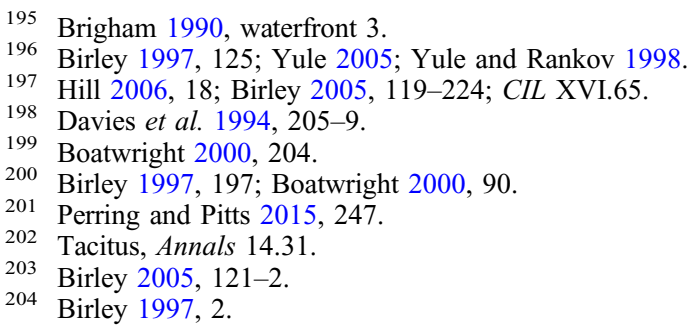


this was for the public humiliation of eminent individuals rather than the fate of entire hosts. Similarly, large numbers of hostile prisoners bound for execution in the amphitheatre are unlikely to have been marched long distances and are more likely to have been captured locally. A rebellion that drew on local support would, in turn, have added to the case for the visible military response represented by the Cripplegate fort. This was much larger and more imposing than the Neronian fort built in London after the Boudican revolt, influenced in part by a shift from earthen to masonry construction that characterised the architecture of the second century, and built as much to intimidate as to reassure.

The evidence for decapitation and denial of burial witnessed by some Walbrook skulls suggests exceptional punitive retribution. The treatment of those who had betrayed Rome, as in earlier civil wars, provided an important point of reference to the officer class in the army. If a rebellion had found local support this need not have been exclusively British. DNA and stable isotope analysis from one of the London Wall skulls indicates that the deceased, a black-haired and brown-eyed male, was probably not born in Britain and that his mother's family came from eastern Europe or the Near East. ${ }^{205}$ It should occasion no surprise if a British revolt drew slaves and disaffected soldiers to its cause. Many of Rome's most accomplished enemies were deserters from its own armies and the worst punishment was reserved for this enemy from within. ${ }^{206}$ The further DNA and stable isotope analysis of Walbrook skulls is eagerly awaited.

New waterfront facilities found on river slopes beneath the Tower, outside the Roman city, appear to have been temporary works of this period. Given their location, some distance from the urban port, it might make sense to see them as arrangements for military supply, providing for ships coming upriver to the border of the city. These facilities may, in turn, have been linked with new roads designed to bypass the town centre and facilitate communication with Verulamium. If timbers had been felled on demand, as likely at this date, the works were planned before the spring of A.D. 127. Two possibilities, both speculative, present themselves. The wharf here could have been built in the immediate aftermath of London's destruction, in temporary replacement of facilities awaiting restoration in the town centre. Alternatively, the waterfront preceded the fire and was built to support campaigns before the conclusion of war. In either case the evidence is consistent with a chronology that dates both fire and war to A.D. $125 / 6$.

Victory may have been sufficiently comprehensive to allow troops to be withdrawn from Britain before the end of A.D. 127. London, however, remained under garrison. Hadrianic construction of the post-fire years involved rebuilding the port from $c$. A.D. 128 (waterfront 4) and the construction of the new fort and vicus, where houses were built using timbers felled in A.D. 129. The masonry amphitheatre was completed at about this time, which might also be the date of new baths and temples in Southwark. ${ }^{207}$ These activities testify to a swift programme of reconstruction, perhaps drawing on direct imperial patronage in the same fashion as other cities devastated by war. ${ }^{208}$

Auxiliary cavalry are likely to have been at the forefront in any policing exercises and the evidence from London adds support to the suggestion that head-hunting practices inspired by Gallic tradition had become normalised within the early second-century Roman army. While the Walbrook skulls may have been trophies obtained in reprisals that continued over several decades and certainly drew on practices that continued for the better part of two centuries, the exceptional scale of the second-century evidence is perhaps more consistent with a major massacre concentrated within a shorter war. An event of this nature could have contributed to

205 Shaw et al. 2016.

206 Haynes 2013, 364; Shaw 1993, 335-6.

207 Perring 2015, 30.

208 Boatwright 2000, 172-4; Birley 1997, 74. 
exaggerated ritual practices within the upper Walbrook vicus, which drew on warrior culture associated with auxiliary troops, whose identities were in part formed in Gaul and Germany.

London's military occupation and aspects of these ritual practices lasted for some 40 years. The city appears to have witnessed a severe contraction in the Antonine period, a process which may have been exacerbated by the plague of $c$. A.D. $165 .{ }^{209}$ The arrival of pestilence might have hastened the evacuation of troops no longer needed for policing duties and exaggerated the process of urban contraction. Whatever the cause, the fort was evacuated in the late second century, with a date $c$. A.D. 165 providing a good fit for the evidence. Ritual corpse abuse, sometimes involving the decapitation and display of heads, still occurred on rare occasions in the third century. The ideas involved perhaps influenced those who violently decapitated and then buried the stone head of Mithras when London's Mithraeum was decommissioned. ${ }^{210}$ Practices involving the disposal of human remains were, however, largely expelled from the upper Walbrook valley when it was formally incorporated into the city on the construction of the town wall, probably in Severan urban renewal. ${ }^{211}$

The arguments presented here are necessarily speculative, as we cannot escape the fact that the silence of historical sources leaves us no way of knowing how and why Britain descended into war during Hadrian's reign, while the issue of when is vexed. It is consequently impossible to know what role, if any, London had in such a conflict. What we have, however, are several disparate strands of archaeological evidence that witness a changing urban landscape. Many unusual features to the archaeology of the second-century city find coherent explanation in the argument presented here, that London was destroyed in a Hadrianic war that engendered military occupation and violent repression. This evidence contributes to the wider picture now emerging of London as a city that remained under close imperial control, where the military administration played a vital role in episodes of urban transformation.

209 Perring 2011, 279-80.

210 Shepherd 1998, 85-6, 165-6; Merrifield 1977, 376.

211 Perring 2015, 33-4, fig. 7. 
TABLE 1. CATALOGUE OF HUMAN CRANIA RECOVERED FROM ROMAN CONTEXTS IN AND AROUND THE UPPER WALBROOK. SELECTIVE USE IS MADE HERE, AND ELSEWHERE, OF MUSEUM OF LONDON ALPHA-NUMERIC SITE CODES

Date

? Roman

Context

Unknown (?stream)

Quantity

An

immense

number

? Roman

Unknown (?stream)

Several

? Roman

Unknown (?stream)

? Roman

Unknown (?stream)

? Roman

Unknown (?stream)

? Roman

Unknown

Unknown

Unknown

? Roman

Stream-bed

numbers

$(16+)$
9 ? Roman
$100+$

\section{Site}

Blomfield Street

Road from London

Wall to New Court

Little Bell Alley (now

Copthall Avenue)

Site adjoining Gooch

and Cousens Wool

Warehouse

Gooch and Cousens

Wool Warehouse.

$\mathrm{S}$ of London Wall,

opposite Finsbury

Circus

Queen Victoria Street,

Buckersbury, Charlotte

Row (NSDC site)

London Wall (exact site uncertain)

Old Moorfields Chapel

London Wall Estate

Office, Finsbury Circus

Finsbury House Blomfield Street
Date

\section{found}

1838

$1851-$

1866

$1872-3$

before

1885

c. 1900

1902-3 which 13 went to the Guildhall

Museum and three were held privately (12 now remain with the Museum of London).

\section{Description}

City sewer records: 'an immense number of human skulls were found throughout this street'; none survive.

City sewer records: 'we also found human heads in the same line of work'; none survive.

Two skulls discovered, none survive.

17 crania and three mandibles recovered, now in the Pitt-Rivers Museum, Oxford.

A skull and a mandible in Museum of London collections, which show staining characteristic of Walbrook skulls and may come from the stream. Skulls purchased by Royal College of Surgeons (unpublished); five now in the British Museum (Natural History). Six skulls discovered; none survive.

Upwards of 100 (skulls) discovered at the bottom of the stream filling while other bones were almost wholly absent; none retained.

\section{References}

Marsh and West

1981, no. 2; Smith

1842, 152-3;

Wheeler 1928, 87

Marsh and West

1981, no. 3; Smith

1842, 152-3;

Wheeler 1928, 87

Marsh and West

1981, no. 4; Lane

Fox 1867, 77

Marsh and West

1981, no. 5; Lane

Fox 1867

Marsh and West

1981, no. 6

Marsh and West

1981, no. 7

Marsh and West

1981, no. 8; Reade

1903, 201

Marsh and West

1981, no. 9;

Norman and

Reader 1906, 176

Marsh and West

1981, no. 10;

Norman and

Reader 1906, 176 


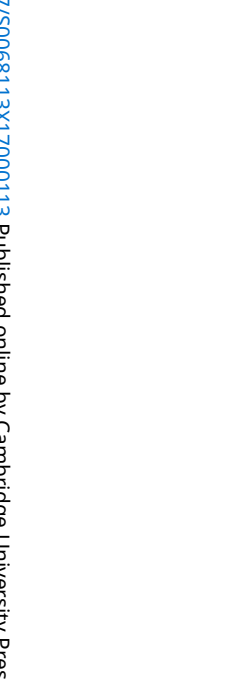

London Wall, outside Carpenters' Hall$$
12
$$$$
13
$$$$
\text { ? Roman }
$$

Unknown

Unknown

Unknown (?stream)

Unknown

Roadside ditch

120-40
122 London Wall

'Walbrook', site

uncertain possibly

Blomfield Street

Bank of England

Finsbury House,

Blomfield Street

13 Copthall Avenue

Finsbury House,

Blomfield Street

15-35 Copthall Avenue

(OPT81)

52-63 London Wall

(LOW 88)

River Plate House, 7-11

Finsbury Circus

(RIV87)
120-200
Two skulls excavated neither of which survive.

1920

One skull found now in Museum of London.

before

1925

$1928-$

34

1938

1967

1981

1982

82

One skull now in Museum of London.

Nine skulls survive, one in Bank's collection, others with Museum of London.

Two more skulls found during minor alterations and now in the Museum of London.

A human skull was recorded from the southern part of the site in a layer of black mud.

Part of a skull found by workmen in October 1981.

Three skulls of young men from a roadside ditch and stream channel dated A.D. 120-40. A sliver of bone detached from the angle of a mandible was consistent with a heavy blow by a sword.

39 skulls of young men from waterlogged pits dug (c. A.D. 120-60) adjacent to a Walbrook channel, and showing a range of pre-mortem (8/39) and peri-mortem (20/39) injuries.

Skull fragments in a flood deposit (Pd 3 [220]).
Marsh and West 1981, no. 11 Norman and

Reader 1906, 176 Marsh and West 1981, no. 12;

Lambert 1921, 75 Marsh and West 1981, no. 13

Marsh and West 1981, no. 14

Marsh and West 1981 , no. 10

Marsh and West 1981, no. 15

Marsh and West 1981 , no. 10

Cotton 1996;

Maloney and de Moulins 1990, 34;

Marsh and West 1981, 97

Cotton 1996;

Redfern and

Bonney 2014

Harward et al. 2015, 18, 36 
20 A.D. 120-200

Disturbed deposits, and fills of pits and ditches associated with water channels

\section{2nd \\ Ditches and water}

century

channels

Unknown

Quarry pit and open

A.D.

120-60/

area

24 Roman

Late 2nd century east bank of

Walbrook

25 c. A.D.

Roadside ditch gravel deposits on
Liverpool House, 15-17 Eldon Street (ELD88)

London Wall (MRL98)

6 Broad Street and

Blomfield Street (BDC03)

35 Basinghall Street (BAZ05)

Liverpool Street, Broadgate (XSM10)

Liverpool Street
Date

found

\section{Description}

An isolated skull fragment $(\mathrm{Bu} 2)$ disarticulated by water or other disturbance, close to an area of

inhumation burials. Two skulls dislodged and moved by water flow (Bu84 and 85) within ditch (S5).

Three skulls (two adult males, one within a ditch (S5). One of the male skulls also associated with upper vertebrae and collar bone (Bu77-79). Skull fragments and long bones in second-century drainage ditches and some showing dog gnawing and

post-mortem cuts. Also associated with horse bones.

2003-4 Skulls of ten adults and two sub-adults, including examples stained with

vivianite, found in excavation of the Blomfield Street Channel (sewer) with few related skeletal fragments.

Deposits also included fragments of horse.

Remains in quarry pit included the skull fragments of a possible female adolescent or young adult. A second adult cranium found within an open area had a shallow, smooth circular depression which could have been a Skulls recovered by workmen during construction of Crossrail beneath

Skulls set in a row within a ditch adult ?female) in a poorly defined pit later reworking of these channels, well-healed blunt force injury or a depression from an overlying cyst. Liverpool Street. marking the south side of a Roman road during construction of Crossrail.

\section{References}

Harward et al. $2015,19,43,48$

Butler 2006, 40-2

Harward et al. $2015,8,49,130$

Wardle et al. 2015 24, 154

Harward et al. 2015, 131; Keily 2017, 60

Keily 2017, 60 


\begin{tabular}{|c|c|c|c|c|c|c|c|}
\hline & Date & Context & Quantity & Site & $\begin{array}{l}\text { Date } \\
\text { found }\end{array}$ & Description & References \\
\hline 26 & Roman & Unknown & 1 & $\begin{array}{l}\text { Borough High Street, } \\
\text { Southwark }\end{array}$ & 1867 & A human skull in a samian 'tazza'. & Wheeler 1928,167 \\
\hline 27 & $\begin{array}{l}\text { Probably 1st } \\
\text { century }\end{array}$ & Unknown & 1 & $\begin{array}{l}\text { Newgate Street (exact } \\
\text { site unknown) }\end{array}$ & $\begin{array}{l}\text { before } \\
1903\end{array}$ & $\begin{array}{l}\text { Skull stained brown, found without } \\
\text { lower jaw. Male } 22-35 \text { years old. }\end{array}$ & $\begin{array}{l}\text { Marsh and West 1981, } \\
94 \text { (B) }\end{array}$ \\
\hline 28 & $\begin{array}{l}\text { Probably } 1 \text { st } \\
\text { century }\end{array}$ & $\begin{array}{l}\text { Not known, but } \\
\text { found in gravel }\end{array}$ & 1 & $\begin{array}{l}\text { Old GPO, St } \\
\text { Martin-le-Grand (161-2 } \\
\text { Cheapside) }\end{array}$ & 1926 & $\begin{array}{l}\text { Skull stained brown found without lower } \\
\text { jaw. Male } 22-24 \text { years old. }\end{array}$ & $\begin{array}{l}\text { Marsh and West 1981, } \\
94 \text { (A) }\end{array}$ \\
\hline 30 & Flavian? & Well & 1 & $\begin{array}{l}\text { Aldemary House, } 61-2 \\
\text { Queen Street, Pancras } \\
\text { Lane (BOLSA) }\end{array}$ & $1953-4$ & $\begin{array}{l}\text { Cranium of a } 35-45 \text {-year-old male, } \\
\text { penetrated by a wooden stake, in an } \\
\text { organic deposit (Layer } 2 \text { ) within a well } \\
(22) \text {. }\end{array}$ & $\begin{array}{l}\text { Marsh and West 1981, } \\
95(\mathrm{C}) \text {; Wilmott 1982, } \\
9 \text { and } 75\end{array}$ \\
\hline 31 & Late 1st century & $\begin{array}{l}\text { Found in a } \\
\text { 'stratum' }\end{array}$ & 1 & $\begin{array}{l}\text { Coutt's Bank, Lombard } \\
\text { Street }\end{array}$ & 1959 & Male adult skull fragment, not stained. & $\begin{array}{l}\text { Marsh and West 1981, } \\
95(\mathrm{H})\end{array}$ \\
\hline 32 & Mid-2nd century & $\begin{array}{l}\text { Cripplegate fort } \\
\text { ditch }\end{array}$ & 1 & Aldermanbury & 1965 & $\begin{array}{l}\text { Skull fragment, not stained, found with } \\
\text { three smashed pots. }\end{array}$ & $\begin{array}{l}\text { Marsh and West 1981, } \\
95(\mathrm{G})\end{array}$ \\
\hline 33 & Late Roman & City wall bank & 1 & Old Bailey & $1966-9$ & $\begin{array}{l}\text { Skull found in late Roman addition to } \\
\text { City wall bank, adjacent to a known } \\
\text { cemetery. }\end{array}$ & $\begin{array}{l}\text { Marsh and West 1981, } \\
95 \text { (I) }\end{array}$ \\
\hline 34 & Claudian? & Large ditch & 1 & $\begin{array}{l}207 \text { Borough High } \\
\text { Street, Southwark }\end{array}$ & 1972 & $\begin{array}{l}\text { Cranium of a } c .30 \text {-year-old female with } \\
\text { two nearly complete samian vessels. }\end{array}$ & $\begin{array}{l}\text { Ferretti and Graham } \\
\text { 1978; Marsh and West } \\
\text { 1981, } 95 \text { (D) }\end{array}$ \\
\hline 35 & $\begin{array}{l}\text { Flavian - } \\
\text { probably earlier } \\
\text { than } c \text {. A.D. } 85\end{array}$ & $\begin{array}{l}\text { Waterfront } \\
\text { deposits }\end{array}$ & 1 & $\begin{array}{l}\text { Upper Thames Street } \\
\text { (TST78) }\end{array}$ & 1978 & $\begin{array}{l}\text { Skull stained brown found without lower } \\
\text { jaw. Adult male. Probably associated } \\
\text { with a timber waterfront dated } c \text {. A.D. } 85 \text {. }\end{array}$ & $\begin{array}{l}\text { Marsh and West 1981, } \\
95(\mathrm{~F})\end{array}$ \\
\hline 36 & $\begin{array}{l}\text { Earlier than } c \text {. } \\
\text { A.D. } 80\end{array}$ & $\begin{array}{l}\text { Open quarry } \\
\text { pit/pond }\end{array}$ & 1 & Watling Court (WAT78) & 1978 & $\begin{array}{l}\text { A human skull without its lower jaw } \\
\text { found at base of waterlogged fills of an } \\
\text { open quarry pit which had been sealed } \\
\text { by a building built with timbers felled } \\
\text { A.D. } 60-105 \text { and containing largely } \\
\text { Flavian material. }\end{array}$ & $\begin{array}{l}\text { Perring and Roskams } \\
1991,41\end{array}$ \\
\hline 37 & $\begin{array}{l}\text { Mid- to late } 4 \text { th } \\
\text { century }\end{array}$ & Ditch & 1 & $\begin{array}{l}8-10 \text { Crosswall } \\
\text { (XWL79) }\end{array}$ & 1979 & $\begin{array}{l}\text { Part of a skull with a coin of A.D. } 346-61 \\
\text { in backfill of town ditch. }\end{array}$ & $\begin{array}{l}\text { Richardson 1980, } \\
\text { 385; Schofield and } \\
\text { Maloney 1998, 162; } \\
\text { Cotton 1996, } 89\end{array}$ \\
\hline
\end{tabular}




\section{Date}

Context

Quantity

42 A.D. $120-60$

Thames

waterfront infil

Ditch

one

Late 1 st to 2 nd century

45 Roman

Ditch

$46 \quad 1$ st century

$47 \quad$ Late 1 st or early 2nd century

dumps

Ditch

Ditch

\section{Site}

119-21 Cannon Street

(LIB82)

145-6 Leadenhall Street (LEN89)

Old Bailey site (VAL88)

Regis House (KWS94)

Baltic Exchange, St Mary Axe (BAX95)

52-56 Lant Street, Southwark (LTU03)

30-37 Walbrook, 97101 Cannon Street (WAO06)

Ewer Street Car Park,

Southwark

Bucklersbury House

\section{Date}

\section{found}

1982

1989

90

989-

$1995-6$

\section{3}

28-30 Trinity Street, Southwark
1995-6

\section{Description}

Human skull with the skeletons of two dogs and a large number of sherds of Neronian flagons and amphorae found within a box at the base of a well.

Pit in an open area adjacent to early

second-century buildings contained two human skulls.

A human skull, in a pit adjacent to the outer wall line of a third-century temple. Possibly a foundation deposit.

Adult skulls, arm and leg bones found in the Neronian quay infill.

Three human skulls within large ditch,

perhaps the town ditch. No other human remains present. Remains of a horse and two dogs were found nearby.

The primary fill of a small ditch

contained two adult skulls (male and female), the secondary fill also contained a skull fragment, possibly from an infant. The feature lay some distance to the south of an inhumation cemetery.

2006-7 A complete adult human cranium recovered from a make-up deposit for a road constructed in post-Boudican rebuilding.

Human skull from ditch.

Intact human cranium in waterside dumps beneath a late first-century timber platform.

Large quantities of disarticulated bone from fills of a large ditch associated with a small inhumation cemetery, with a group of three skulls at the base of part of the feature.

\section{References}

Richardson 1983 ,

277; Schofield and

Maloney 1998, 183

Cotton 1996, 89

Filer 1991, 275;

Cotton 1996, 89

Schofield and

Maloney 1998 171;

Cotton 1996, 89

Perring and Brigham

2000, 148

Howe 2002, 12

Ridgeway et al. 2013 11

Powers in Blair 2010 88

Booth 2013, 333

Booth 2014, 373

Langthorne 2015 , 225-9 


\section{ACKNOWLEDGEMENTS}

I am grateful to Kenny Scott and Louise Rayner for discussing the ideas developed here, to John Pearce for commenting on an earlier draft, and to the two anonymous referees whose thoughtful comments helped to sharpen the arguments. Justin Russel prepared the illustrations with customary efficiency.

Centre for Applied Archaeology, Institute of Archaeology, UCL

d.perring@ucl.ac.uk

\section{ANCIENT SOURCES}

Appian: Roman History, Vol. 4: The Civil Wars, trans. H. White, Loeb Classical Library, Cambridge, Mass./ London (1913)

Arrian: Tactica: Greek and Roman Military Writers: Selected Readings, trans. B. Campbell, London and New York (2004)

Caesar: Alexandrian War. African War. Spanish War, trans. A.G. Way, Loeb Classical Library, Cambridge, Mass./London (1955)

Cicero: 'On the Republic' and 'On the Laws', trans. D. Fott, Ithaca, NY (2014)

Cicero: Pro Sestio. In Vatinium, trans. R. Gardner, Loeb Classical Library, Cambridge, Mass./London (1958)

Digest: The Digest of Justinian, Latin text, eds T. Mommsen with P. Krueger, trans. A. Watson, Philadelphia (1985)

Dio Cassius: Roman History, Vol. 8: Books 61-70, trans. E. Cary and H.B. Foster, Loeb Classical Library, Cambridge, Mass./London (1925)

Diodorus Siculus: Library of History, Vol. 3: Books 4.59-8, trans. C.H. Oldfather, Loeb Classical Library, Cambridge, Mass./London (1939)

Eusebius: Ecclesiastical History: Complete and Unabridged, trans. C.F. Crusé, Peabody, Mass. (1998)

Fronto: Correspondence, Vol. 1, trans. C.R. Haines, Loeb Classical Library, Cambridge, Mass./London (1919)

Horace: 'Carmen Saeculare', Odes and Epodes, trans. N. Rudd, Loeb Classical Library, Cambridge, Mass./ London (2004)

Livy: The History of Rome, Vols 2 and 3, trans. W.M. Roberts, London (1905)

Lucan: The Civil Wars (Pharsalia), trans. J.D. Duff, Loeb Classical Library, Cambridge, Mass./London (1928)

Pliny: Letters, trans. B. Radice, Loeb Classical Library, Cambridge, Mass./London (1989)

Plutarch: 'Cicero' and 'Antony', Lives, Vols 7 and 9, trans. B. Perrin, Loeb Classical Library, Cambridge, Mass./London (1919-20)

SHA: 'Hadrian', Historia Augusta, Vol. 1, trans. D. Magie (1921), Loeb Classical Library, Cambridge, Mass./ London (1921)

Strabo: Geography, Vol. 2: Books 3-5, trans. H.L. Jones, Loeb Classical Library, Cambridge, Mass./London (1923)

Suetonius: 'Galba', The Lives of the Twelve Caesars, trans. J.C. Rolfe, Loeb Classical Library, Cambridge, Mass./London (1914)

Tacitus: Histories: Books 4-5. Annals: Books 1-3, trans. C.H. Moore, Loeb Classical Library, Cambridge Mass./London (1931)

Tacitus: Annals: Books 13-16, trans. C.H. Moore, Loeb Classical Library, Cambridge Mass./London (1937)

Twelve Tablets: The Library of Original Sources. Vol. III: The Roman World, trans. O.J. Thatcher, Milwaukee (1901)

Valerius Maximus: Memorable Doings and Sayings, Vol. 2: Books 6-9, trans. D.R Shackleton Bailey, Loeb Classical Library, Cambridge, Mass./London (2000) 


\section{BIBLIOGRAPHY}

Armit, I. 2012: Headhunting and the Body in Iron Age Europe, Cambridge

Ash, R. 1997: 'Severed heads: individual portraits and irrational forces in Plutarch's Galba and Otho', in J. M. Mossman (ed.), Plutarch and his Intellectual World: Essays on Plutarch, London, 189-214

Bateman, N., and Milne, G. 1983: 'A Roman harbour in London; excavations and observations near Pudding Lane, City of London 1979-82', Britannia 14, 207-26

Bateman, N., Cowan, C., and Wroe-Brown, R. 2008: London's Roman Amphitheatre: Guildhall Yard, City of London, MoLAS Monograph 35, London

Bauman, R.A. 1996: Crime and Punishment in Ancient Rome, London

Benfield, S., and Garrod, S. 1992: 'Two recently-discovered Roman buildings at Colchester', Essex Archaeology and History 14, 25-38

Bird, J., Hassall, M., and Sheldon, H. 1996: Interpreting Roman London. Papers in Memory of Hugh Chapman, Oxford

Birley, A.R. 1997: Hadrian: The Restless Emperor, London

Birley, A.R. 1998: 'A new tombstone from Vindolanda', Britannia 29, 299-306

Birley, A.R. 2002: Garrison Life at Vindolanda: A Band of Brothers, Stroud

Birley, A.R. 2005: The Roman Government of Britain, Oxford

Birley, A.R. 2007: 'The frontier zone in Britain: Hadrian to Caracalla', in De Blois and Lo Cascio 2007, $355-70$

Blair, I. 2010: 'The Walbrook. St Swithin's House, Walbrook House and Granite House, London EC4, City of London', unpub. MoLA Post-excavation Assessment

Blair, I., Spain, R., Swift, D., Taylor, T., and Goodburn, D. 2006: 'Wells and bucket-chains: unforeseen elements of water supply in early Roman London', Britannia 37, 1-52

Bluer, R., Brigham, T., and Nielson, R. 2006: Roman and Later Development East of the Forum and Cornhill: Excavations at Lloyd's Register, 71 Fenchurch Street, City of London, MoLAS Monograph 30, London

Blurton, T.R. 1977: 'Excavations at Angel Court, Walbrook, 1974', Transactions of the London and Middlesex Archaeological Society 28, 14-100

Boatwright, M.T. 2000: Hadrian and the Cities of the Roman Empire, Princeton

Booth, P. 2013: 'Roman Britain in 2012: Greater London', Britannia 44, 324-33

Booth, P. 2014: 'Roman Britain in 2013: Greater London', Britannia 45, 370-9

Bowman, A.K., and Thomas, J.D. 1991: 'A military strength report from Vindolanda', Journal of Roman Studies 81, 62-73

Bradley, R., and Gordon, K. 1988: 'Human skulls from the river Thames, their dating and significance', Antiquity 62 (236), 503-9

Braithwaite, G. 2007: Faces from the Past: A Study of Roman Face Pots from Italy and the Western Provinces of the Roman Empire, BAR International Series 1651, Oxford

Breeze, D.J. 1983: review of B. Philp (1981), The Excavation of the Roman Forts of the Classis Britannica at Dover, 1970-1977, Britannia 14, 372-5

Breeze, D.J. 2003: 'Warfare in Britain and the building of Hadrian's Wall', Archaeologia Aeliana 32, 13-16

Breeze, D.J., Dobson, B., and Maxfield, V. 2012: 'Maenius Agrippa, a chronological conundrum', Acta Classica 55, 17-30

Brigham, T. 1990: 'The late Roman waterfront in London', Britannia 21, 99-184

Brigham, T. 1998: 'The port of Roman London', in Watson 1998, 23-34

Brigham, T., and Watson, B. 1996: 'Current archaeological work at Regis House in the City of London (part 2)', London Archaeologist 8 (3), 63-9

Brigham, T., and Woodger, A. 2001: Roman and Medieval Townhouses on the London Waterfront: Excavations at Governor's House, City of London, MoLAS Monograph 9, London

Bruce, G., Perring, D., Stevens, T., and Melikian, M. 2009: 'Roman and medieval activity in the upper Walbrook valley: excavations at 12-18 Moorgate, City of London, EC2, 1997', Transactions of the London and Middlesex Archaeological Society 60, 73-89

Bull, S. 2007: Triumphant Rider: The Lancaster Roman Cavalry Tombstone, Lancaster 
Busch, A.W. 2007: "Militia in Urbe”. The military presence in Rome', in De Blois and Lo Cascio 2007, 315-41

Butler, J. 2006: Reclaiming the Marsh: Archaeological Excavations at Moor House, City of London, PCA Monograph 6, London

Butler, J., and Ridgeway, V. 2009: Secrets of the Gardens: Archaeologists Unearth the Lives of Roman Londoners at Drapers' Gardens, London, London

Campbell, B. 2000: The Writings of the Roman Land Surveyors: Introduction, Text, Translation and Commentary, Journal of Roman Studies Monograph 9, London

Carr, G.C. 2007: 'Excarnation to cremation: continuity or change?', in C. Haselgrove and T. Moore (eds), The Later Iron Age in Britain and Beyond, Oxford, 444-53

Casey, J. 1987: 'The coinage of Alexandria and the chronology of Hadrian', in H. Huvelin, M. Christol and G. Gautier (eds), Mélanges de numismatique offerts à Pierre Bastien, Wetteren, 65-72

Casson, L., Drummond-Murray, J., and Francis, A. 2014: Romano-British Round Houses to Medieval Parish. Excavations at 10 Gresham Street, City of London, 1999-2002, MoLA Monograph 67, London

CIL: Corpus Inscriptionum Latinarum (1863-)

Cipin, I. 2015: '8-10 Paul Street, Shoreditch, London, EC2A 4JH: assessment of an archaeological watching brief', unpub. Pre-Construct Archaeology report R12029

Clarke, G. 1979: The Roman Cemetery at Lankhills, Pre-Roman and Roman Winchester 3.2, Oxford

Coarelli, F., Brizzi, B., Conti, C., Meneghini, R., and Zanker, P. 2000. The Column of Trajan, Rome

Combe, P., Grew, F., Hayward, K., and Henig, M. 2015: Roman Sculpture from London and the South-East. Corpus Signorum Imperii Romani, Great Britain 1.10, Oxford

Cotton, J. 1996: 'A miniature chalk head from the Thames at Battersea and the "Cult of the Head" in Roman London', in Bird et al. 1996, 85-96

Cowie, R., Thorp, A., and Wardle, A. 2013: Roman Roadside Settlement and Rural Landscape at Brentford: Archaeological Investigations at Hilton London Syon Park Hotel, 2004-10, MoLAS Archaeology Studies Series 29, London

Craig, R., Knüsel, C.J., and Carr, G.C. 2005: 'Fragmentation, mutilation and dismemberment: an interpretation of human remains in Iron Age sites', in M. Parker Pearson and N. Thorpe (eds), Violence, Warfare, and Slavery, BAR International Series, Oxford, 165-80

Crummy, N. 2011: 'Travel and transport', in L. Allason-Jones, Artefacts in Roman Britain: Their Purpose and Use, Cambridge, 46-67

Crummy, P. 1984: Excavations at Lion Walk, Balkerne Lane and Middleborough, Colchester, Colchester Archaeological Report 3, Colchester

Curle, J. 1911: A Roman Frontier Post and its People: The Fort of Newstead in the Parish of Melrose, Glasgow

Davies, B., Richardson, B., and Tomber, R. 1994: A Dated Corpus of Early Roman Pottery from the City of London, CBA Research Report 98, London

Davies, R.W. 1977: 'Cohors I Hispanorum and the garrisons of Maryport', Transactions of the Cumberland and Westmorland Antiquarian Archaeological Society 77, 7-16

Davison, D.P. 1989: The Barracks of the Roman Army from the First to Third Centuries AD, BAR International Series 472, Oxford

De Blois, L., and Lo Cascio, E. (eds) 2007: The Impact of the Roman Army (200 BC-AD 476): Economic, Social, Political, Religious and Cultural Aspects, Leiden

Denyer, C.H. 1935: St. Pancras through the Centuries, London

Dixon, K.R., and Southern, P. 1992: The Roman Cavalry: From the First to the Third Centuries AD, London

Dunkle, R. 2008: Gladiators: Violence and Spectacles in Ancient Rome, London

Dunning, G.C. 1945: 'Two fires of Roman London', Antiquaries Journal 25, 48-77

Dunwoodie, L., Harward, C., and Pitt, K. 2015: An Early Roman Fort and Urban Development on Londinium's Eastern Hill: Excavations at Plantation Place, City of London, 1997-2003, MOLA Monograph 65, London

Eck, W. 1999: 'The Bar Kokhba revolt; the Roman point of view', Journal of Roman Studies 89, 76-89

Edwards, Y.H., Weisskopf, A., and Hamilton, D. 2009; 'Age, taphonomic history and mode of deposition of human skulls in the River Thames', Transactions of the London and Middlesex Archaeological Society 60, 35-51 
Ferretti, E., and Graham, A.H. 1978: '201-211 Borough High Street', in J. Bird, A. Graham, H. Sheldon and P. Townend (eds), Southwark Excavations 1972-1974, London and Middlesex Archaeological Society and Surrey Archaeological Society 1, London, 53-176

Fields, N. 2005: 'Headhunters of the Roman army', in Hopkins and Wyke 2005, 55-66

Filer, J. 1991: 'Excavation round-up 1990: part 1, City of London', London Archaeologist 6 (10), 272-8

Frere, S.S. 2000: 'M. Maenius Agrippa, the "Expeditio Britannica" and Maryport', Britannia 31, 23-8

Furhmann, C.J. 2012: Policing the Roman Empire: Soldiers, Administration and Public Order, Oxford

Fulford, M., and Holbrook, N. (eds) 2015: The Towns of Roman Britain: The Contribution of Commercial Archaeology since 1990, Britannia Monograph 27, London

Geoffrey of Monmouth: The History of the Kings of Britain: An Edition and Translation of De gestis Britonum (Historia regum Britanniae), trans. N. Wright (2007), Woodbridge

Goldsworthy, A.K. 1998: The Roman Army at War 100 BC-AD 200, Oxford

Goodburn, D. 2008: 'Timber', in T. Bradley and J. Butler, From Temples to Thames Street - 2000 Years of Riverside Development; Archaeological Excavations at the Salvation Army International Headquarters, London, Pre-Construct Archaeolology Monograph 7, London, 41-51

Green, M. 2001: Dying for the Gods: Human Sacrifice in Iron Age and Roman Europe, Stroud

Haglund, W.D. 1993: 'Disappearance of soft tissue and the disarticulation of human remains from aqueous environments', Journal Forensic Science 38 (4), 806-15

Hall, J. 1996: 'The cemeteries of Roman London', in Bird et al. 1996, 57-84

Hall, J. 2014: 'With criminal intent? Forgers at work in Roman London', Britannia 45, 165-94

Hanson, W.S. 2012: 'Newstead and Roman Scotland: the Flavian to Antonine periods', in F. Hunter and L.J. F. Keppie (eds), A Roman Frontier Post and its People a Hundred Years on: Newstead 1911-2011, Edinburgh, 62-75

Harding, V. 1990: 'The population of London, 1550-1700: a review of the published evidence', London Journal 15.2, 111-15

Harward, C., Powers, N., and Watson, S. 2015: The Upper Walbrook Cemetery of Roman London: Excavations at Finsbury Circus, City of London, 1987-2014, MoLAS Archaeology Studies Series 32, London

Hassall, M.W.C. 2012: 'The $2^{\text {nd }}$-century AD garrison of Londinium', in Shepherd 2012, 158-63

Haynes, I. 2013: Blood of the Provinces: The Roman Auxilia and the Making of Provincial Society from Augustus to the Severans, Oxford

Hencken, T. 1938: 'The excavation of the Iron Age camp on Bredon Hill, Gloucestershire 1935 to 1937', Archaeological Journal 95, 88-111

Hill, J., and Rowsome, P. 2011: Roman London and the Walbrook Stream Crossing: Excavations at 1 Poultry and Vicinity, City of London, MoLA Monograph 37, London

Hill, P.R. 2006: The Construction of Hadrian's Wall, Stroud

Hillam, J. 1986: Tree-ring Dating in the City of London: The Bridgehead Sites and the Dating of the Roman Harbour, English Heritage AML Report 4794

Hinard, F. 1987: 'Spectacle des executions et espace urbain', in L'Urbs, espace urbain et histoire (Ier siècle av. J.-C.-IIIe siècle ap. J.-C.), Actes du colloque international organisé par le Centre national de la recherche scientifique et l'Ecole française de Rome (8-12 mai 1985), EFR 98, Rome, 111-25

Hobley, B., and Schofield, J.A. 1977: 'Excavations in the City of London. First interim report, 1974-1975', Antiquaries Journal 57, 31-66

Hoffman, B. 2013: The Roman Invasion of Britain: Archaeology v History, Barnsley

Holder, P. 2003: 'Auxiliary deployment in the reign of Hadrian', Bulletin of the Institute of Classical Studies 46 (S81), 101-14

Hope, V.M. 2000: 'Contempt and respect: the treatment of the corpse in ancient Rome', in V.M. Hope and E. Marshall (eds), Death and Disease in the Ancient City, London, 104-27

Hope, V.M. 2007: Death in Ancient Rome: A Sourcebook, London

Hopkins, A., and Wyke, M. (eds) 2005: Roman Bodies: Antiquity to the Eighteenth Century, London

Howe, E. 2002: Roman Defences and Medieval Industry: Excavations at Baltic House, City of London, London, MoLAS Monograph 7, London

Howe, E., and Lakin, D. 2004: Roman and Medieval Cripplegate, City of London: Excavations 1992-8, MoLAS Monograph 21, London 
Hurst, H. 1999: 'Civic space at Glevum', in H. Hurst (ed.), The Coloniae of Roman Britain: New Studies and a Review. Papers of the Conference held at Gloucester on 5-6 July 1997, Journal of Roman Archaeology Supplementary Series 36, Portsmouth, RI, 152-60

Hyland, A.H. 1990: Equus: The Horse in the Roman World, New Haven and London

Isserlin, R.M.J. 1997: 'Thinking the unthinkable: human sacrifice in Roman Britain?', in K. Meadows, C. Lemke and J. Heron (eds), TRAC 96. Proceedings of the Sixth Annual Theoretical Roman Archaeology Conference, Oxford, 91-100

Jarrett, M.G. 1976: 'An unnecessary war', Britannia 7, 145-51

Jones, P. 2010: Roman and Medieval Staines: The Development of the Town, Woking

Keily, J. 2017: Tunnel: The Archaeology of Crossrail, London

Knüsel, C.J., and Carr, G.C. 1995: 'On the significance of the crania from the river Thames and its tributaries', Antiquity 69, 162-9

Kyle, D.G. 1998: Spectacles of Death in Ancient Rome, London

Lambert, F. 1921: 'Some recent excavations in London', Archaeologia 71, 55-112

Lane Fox, A.H. 1867: 'A description of certain piles found near London Wall and Southwark, possibly the remains of pile buildings', Anthropological Review 5, 71-80

Langthorne, J.Y. 2015: 'Human bone', in D. Killock, Temples and Suburbs: Excavations at Tabard Square, Southwark, PCA Monograph 18, London, 225-30

Leary, J., and Butler, J. 2012: Roman Archaeology in the Upper Reaches of the Walbrook Valley. Excavations at 6-8 Tokenhouse Yard, London EC2, London

Lees, D., Woodger, A., and Orton, C. 1989: 'Excavations in the Walbrook valley', London Archaeologist $6(5), 115-19$

Lennon, J.J. 2014: Pollution and Religion in Ancient Rome, Cambridge

Loe, L. 2003: 'Specialist report on the human skull (8658) from Vindolanda, Northumberland', in A. Birley (ed.), Vindolanda Report 2003 Volume I: The Excavation of 2001-2002: Civilian Settlement, Severan and Second Century Forts and the Pre-Hadrianic Occupation, with a Report on the Trial Excavations at Carvoran, Hexham, 213-49

Lyon, J. 2007: Within these Walls: Roman and Medieval Defences North of Newgate at the Merrill Lynch Financial Centre, City of London, MoLAS Monograph 33, London

Maloney, C., with de Moulins, D. 1990: The Upper Walbrook Valley, The Archaeology of Roman London 1, CBA Research Report 69, London

Marks, A. 1908: Tyburn Tree: Its History and Annals, London

Marsh, G. 1981: 'London's samian supply and its relationship to the development of the Gallic samian industry', in A.C. and A.S. Anderson (eds), Roman Pottery Research in Britain and North-West Europe. Papers Presented to Graham Webster, BAR International Series 13, Oxford, 173-238

Marsh, G., and West, B. 1981: 'Skullduggery in Roman London', Transactions of the London and Middlesex Archaeological Society 32, 86-102

Mays, S., and Steele, J. 1996: 'A mutilated human skull from Roman St Albans, Hertfordshire, England', Antiquity 70, 155-61

McKenzie, M. 2011: 'Roman, medieval and later occupation at Lion Plaza, 1-18 Old Broad Street and 41-53 Threadneedle Street, London, EC2', Transactions of the London and Middlesex Archaeological Society 62, $1-30$

Merrifield, R. 1977: 'Art and religion in Roman London: an inquest on the sculptures of Londinium', in J. Munby and M. Henig (eds), Roman Life and Art in Britain, BAR British Series 41, Oxford, 375-406

Merrifield, R. 1983: London: City of the Romans, London

Milne, G. 1992: From Roman Basilica to Medieval Market: Archaeology in Action in the City of London, London

Norman, P., and Reader, F.W. 1906: 'Recent discoveries in connexion with Roman London', Archaeologia $60,169-250$

Parnell, G. 1985: 'The Roman and medieval defences and the later development of the inmost ward, Tower of London: excavations 1955-77', Transactions of the London and Middlesex Archaeological Society 36, $1-80$

Parnum, A., and Cotton, J. 1983: 'Recent work in Brentford: excavations and observations 1974-82', London Archaeologist 4(12), 318-25 
Pearce, J. 2013: Contextual Archaeology of Burial Practice. Case Studies from Roman Britain, BAR British Series 508, Oxford

Pearce, J. 2015: 'Urban exits: commercial archaeology and the study of death rituals and the dead in the towns of Roman Britain', in Fulford and Holbrook 2015, 138-66

Perez-Sala, M., and Shepherd, J. 2008: 'The cullet dump and evidence of glass working', in N. Bateman, C. Cowan and R. Wroe-Brown, London's Roman Amphitheatre: Guildhall Yard, City of London, MoLAS Monograph Series 35, London, 142-6

Perring, D. 1991: Roman London, London

Perring, D. 2002: The Roman House in Britain, London

Perring, D. 2011: 'Two studies on Roman London: A. London's military origins - B. Population decline and ritual landscapes in Antonine London', Journal of Roman Archaeology 24 (1), 249-82

Perring, D. 2015: 'Recent advances in the understanding of Roman London', in Fulford and Holbrook 2015, 20-43

Perring, D., and Brigham, T. 2000: 'London and its hinterland: the Roman period', in Museum of London, The Archaeology of Greater London, MoLAS Monograph, London, 119-70

Perring, D., and Pitts, M. 2015: Alien Cities: Consumption and the Origins of Urbanism in Roman Britain, Portslade

Perring, D., and Roskams, S.P. 1991: The Early Development of Roman London to the West of the Walbrook, CBA Research Report 70, London

Philp, B. 1981: The Excavation of the Roman Forts of the Classis Britannica at Dover, 1970-1977, Kent Monograph Series Research Report 3, Dover

Pitt, K. 2006: Roman and Medieval Development South of Newgate: Excavations at 3-9 Newgate Street and 16-17 Old Bailey, City of London, MoLAS Archaeology Studies Series 14, London

Porter, S. 1996: The Great Fire of London, Stroud

Powers, N. 2015: 'The effect of fluvial erosion on the burials', in Harward et al. 2015, 127-32

Reader, F.W. 1903: 'Pile structures in the Walbrook near London Wall', Archaeological Journal 60, 137-212

Rebillard, E. 2009: The Care of the Dead in Late Antiquity, Ithaca and London

Reddaway, T.F. 1940: Rebuilding London after the Great Fire, London

Redfern, R., and Bonney, H. 2014: 'Headhunting and amphitheatre combat in Roman London, England: new evidence from the Walbrook valley', Journal of Archaeological Science 43, 214-26

RIB I: R.G. Collingwood and R.P. Wright (eds), The Roman Inscriptions of Britain I, Inscriptions on Stone (1965)

RIB III: R.S.O. Tomlin, R.P. Wright and M.W.C. Hassall (eds), The Roman Inscriptions of Britain. III. Inscriptions on Stone found or notified between 1 January 1955 and 31 December 2006 (2009)

RIC: H. Mattingly and E.A. Sydenham (eds), The Roman Imperial Coinage II. Vespasian to Hadrian (1926)

Richardson, B. 1980: 'Excavation round-up 1979', London Archaeologist 3 (14), 384-9

Richardson, B. 1983: 'Excavation round-up 1984', London Archaeologist 4 (10), 274-7

Ridgeway, V., Leary, K., and Sudds, B. 2013: Roman Burials in Southwark: Excavations at 52-56 Lant Street and 56 Southwark Bridge Road, PCA Monograph 17, London

Rivet, A.L.F. 1970: 'The British section of the Antonine Itinerary', Britannia 1, 34-82

Roskams, S.P., and Watson, L. 1981: 'The Hadrianic fire of London', London Archaeologist 4 (3), 62-6

Ross, A. 1967: Pagan Celtic Britain, Stroud

Ross, A., and Feachem, R. 1976: 'Ritual rubbish? The Newstead pits', in J.V.S. Megaw (ed.), To Illustrate the Monuments, London

Roth, J.P. 1999: The Logistics of the Roman Army at War (264 BC-AD 235), Leiden

Rowsome, P. 1999: 'The Huggin Hill baths and bathing in London: barometer of the town's changing circumstances?', in J. Delaine and D.E. Johnston (eds), Roman Baths and Bathing: Proceedings of the $I^{\text {st }}$ International Conference on Roman Baths held at Bath, England, 30 March-4 April 1992, Journal of Roman Archaeology Supplementary Series 37, Portsmouth, RI, 262-77

Roxan, M. 1983: 'A Roman military diploma from London', Transactions of the London and Middlesex Archaeological Society 34, 67-72

Russell, M., and Manley, H. 2015: 'Trajan places: establishing identity and context for the Bosham and Hawkshaw heads', Britannia 46, 151-69 
Sankey, D. 2002: 'Roman, medieval and later development at 7 Bishopsgate, London EC2: from a $1^{\text {st }}$-century cellared building to the $17^{\text {th }}$-century properties of the Merchant Taylors' Company', Transactions of the London and Middlesex Archaeological Society 53, 1-24

Schofield, J.A. 1994: 'Saxon and medieval parish churches in the City of London: a review', Transactions of the London and Middlesex Archaeological Society 45, 23-145

Schofield, J.A. 2011: St Paul's Cathedral Before Wren, London

Schofield, J., with Maloney, C. (eds) 1998: Archaeology in the City of London, 1907-1991: A Guide to Records of Excavations by the Museum of London and its Predecessors. The Archaeological Gazetteer Series, Volume 1, London

Schulting, R.J., and Bradley, R. 2013: 'Of human remains and weapons in the neighbourhood of London: new AMS 14C dates on Thames "river skulls" and their European context', Archaeological Journal $170,30-77$

Seeley, F., and Drummond-Murray, J. 2005: Roman Pottery Production in the Walbrook Valley: Excavations at 20-28 Moorgate, City of London, 1998-2000, MoLAS Monograph 25, London

Shaw, B. 1993: 'The bandit', in A. Giardina (ed.), The Romans, Chicago, 300-41

Shaw, H., Montgomery, J., Redfern, R., and Evans, J. 2016: 'Identifying migrants in Roman London using lead and strontium stable isotopes', Journal of Archaeological Science 66, 57-68

Sheldon, H.L., and Schaaf, L. 1978: 'A survey of Roman sites in Greater London', in J. Bird, H. Chapman and J. Clark (eds), Collectanea Londiniensia. Studies in London Archaeology and History Presented to Ralph Merrifield, London and Middlesex Archaeological Society Special Paper 2, London, 59-88

Shepherd, J.D. 1987: 'The pre-urban and Roman topography in the King Street and Cheapside areas of the City of London', Transactions of the London and Middlesex Archaeological Society 38, 11-60

Shepherd, J.D. 1998: The Temple of Mithras, London: Excavations by W. F. Grimes and A. Williams at the Walbrook, London

Shepherd, J.D. 2012: The Discovery of the Roman Fort at Cripplegate, City of London. Excavations by W F Grimes 1947-68, Museum of London Archaeology, London

Smith, C.R. 1842: 'Observations on Roman remains recently found in London', Archaeologia 29, 145-66

Speidel, M. 1978: Guards of the Roman Armies, Antiquitas 1.28, Bonn

Swain, H., and Williams, T. 2008: 'The population of Roman London', in J. Clark, J. Cotton, J. Hall, R. Sherris and H. Swain (eds), Londinium and Beyond: Essays on Roman London and its Hinterland for Harvey Sheldon, CBA Research Report 156, London, 33-9

Swift, D. 2008: Roman Waterfront Development at 12 Arthur Street, City of London, MoLAS Archaeology Studies Series 19, London

Symonds, R.P. 1998: 'Quelques aperçus sur le port romain de Londres provoqués par les travaux du project César', in SFECAG Actes du Congrès d'Istres, 339-48

Tab. Vindol: A.K. Bowman and J.D. Thomas (eds), The Vindolanda Writing-Tablets (Tabulae Vindolandenses II, nos 118-573) (1994)

Tomlin, R.S.O. 2006: 'Was Roman London ever a Colonia? The written evidence', in Wilson 2006b, 49-64

Tomlin, R.S.O. 2016: Roman London's First Voices: Writing Tablets from the Bloomberg Excavations, 2010-14, MoLA Monograph 72, London

Toynbee, J.M.C. 1971: Death and Burial in the Roman World, Oxford

Tucker, K. 2014: 'The osteology of decapitation burials from Roman Britain', in C. Knüsel and M.J. Smith (eds), The Routledge Handbook of the Bioarchaeology of Human Conflict, London and New York, 213-36

Varner, E.R. 2005: 'Execution in effigy: severed heads and decapitated statues in Imperial Rome', in Hopkins and Wyke 2005, 67-82

Voisins, J.L. 1984: 'Les Romains, chasseurs des têtes', in Du châtiment dans la cité: supplices corporels et peine de mort dans le monde antique, Collection de l'École Française de Rome 79, Rome, 241-93

Wacher, J.S. 1974: The Towns of Roman Britain, Berkeley

Wait, G.A. 1985: Ritual and Religion in Iron Age Britain, BAR British Series 149, Oxford

Walker, L. 1984: 'The deposition of the human remains', in B. Cunliffe, Danebury. An Iron Age Hillfort in Hampshire, CBA Research Report 52, York, 442-63

Wardle, A., with Freestone, I., McKenzie, M., and Shepherd, J. 2015: Glass Working on the Margins of Roman London. Excavations at 35 Basinghall Street, City of London, 2005, MoLA Monograph 70, London 
Watson, B. (ed.) 1998: Roman London: Recent Archaeological Research, Journal of Roman Archaeology Supplementary Series 24, Portsmouth, RI

Watson, S. 2014: 'Excavations at 6-12 Basinghall Street and 93-95 Gresham Street, City of London', Transactions of the London and Middlesex Archaeological Society 65, 185-219

West, B. 1996: 'Ritual or fluvial? A further comment on the Thames skulls', Antiquity 70, 190-1

Wheeler, R.E.M. 1928: London: Volume 3, Roman London, Royal Commission on Historical Monuments of England, London

Williams, T.D. forthcoming: The Archaeology of Roman London: the Development of Roman London East of the Walbrook, MoLA Monograph, London

Wilmott, T.D. 1982: 'Excavations at Queen Street, City of London, 1953 and 1960, and Roman timber-lined wells in London', Transactions of the London and Middlesex Archaeological Society 33, 1-78

Wilson, R.J.A. 2006a: 'Urban defences and civic status in early Roman Britain', in Wilson 2006b, 1-47

Wilson, R.J.A. (ed.) 2006b: Romanitas: Essays on Roman Archaeology in Honour of Sheppard Frere on the Occasion of his Ninetieth Birthday, Oxford

Yule, B. 2005: A Prestigious Roman Building Complex on the Southwark Waterfront: Excavations at Winchester Palace, London, 1983-90, MoLAS Archaeology Studies Series 23, London

Yule, B., and Rankov, B. 1998: 'Legionary soldiers in 3rd-c. Southwark', in Watson 1998, 67-77 